Working Paper 14-23

Business Economic Series 09

September 2014
Departamento de Economía de la Empresa

Universidad Carlos III de Madrid

Calle Madrid, 126

28903 Getafe (Spain)

Fax (34-91) 6249607

\title{
Expropriation Risk, Investment Decisions and Economic Sectors
}

\author{
Diana Constanza Restrepo, ${ }^{1}$ Ricardo Correia,${ }^{2}$ \\ Ignacio Peña ${ }^{3}$ and Javier Población ${ }^{4}$
}

This version: August 2014

\begin{abstract}
We build a Real Options model to assess the importance of private provision and the impact of expropriation risk on investment timing, investment volumes, governmental costs and social welfare. We consider two types of businesses (essential and non essential businesses) and two stages (operating and investment opportunities), and answer questions regarding three main topics: the firm's reaction to expropriation risk, the government drivers to expropriate, and the costs this generates in terms of welfare. We find that the firm makes suboptimal investment decisions. When we endogenize the reputational costs of expropriation, results show that the decision of the government regarding the level of political risk will largely depend on the type of business. However, in terms of welfare it is never optimal to expropriate.
\end{abstract}

Key words Expropriation risk, Expropriation Option, Investment option, Abandonment option, Costs of expropriation

JEL classification H80, G38

\footnotetext{
${ }^{1}$ Department of Business Administration - Universidad Carlos III de Madrid

${ }^{2}$ Department of Business Administration - Universidad Carlos III de Madrid

${ }^{3}$ Department of Business Administration - Universidad Carlos III de Madrid

${ }^{4}$ D.G.A. Supervisión, Banco de España and (CUNEF) Colegio Universitario de Estudios Financieros. This paper is the sole responsibility of its author. The views represented here do not necessarily reflect those of the Banco de España.
} 


\section{Expropriation Risk, Investment Decisions and Economic Sectors}

\section{Introduction}

The wave of nationalizations in Africa and Latin America since the last decade has brought fear of expropriation back into the picture. An expropriation can be defined as the seizing of ownership or control rights of the firm by the government. The problem that it poses to investors is that compensation over expropriation in most of the cases is either non existent or below the fair value of the firm. The governments, in turn, find it appealing that expropriations come with the immediate benefit that they obtain from seizing the assets of the firm once investment costs have been sunk.

We use Real Options and build a version of a classical sequential investment timing model in the spirit of McDonald and Siegel (1986) to investigate the investment decisions of a firm and a government in the presence of expropriation risk. The firm decides when to undertake a new investment project and has the option to shut it down if it is no longer profitable. The government must decide when to expropriate the project once it is in operations. With this model, we answer three main questions about governments' drivers for expropriations, firm's reaction to this phenomenon and the cost that it implies in terms of economic welfare.

The first question is related with the drivers of governments to expropriate. The existing literature approaches this question from several perspectives. For instance, governments can be considered social welfare or national income maximizers (Eaton and Gersovitz, 1984; Cole and English, 1991; Raff, 1992), risk averse agents looking for insurance (Rigobon, 2010; Stroebel and van Benthem, 2010), agents responding to political pressures to expropriate foreign firms (Engel and Fischer, 2010; Jensen and Johnston, 2011), or even punishing multinational firms that renege on contracts (Guriev et al., 2011). An additional strand of the literature assumes an opportunistic government trying to maximize the value of an option to expropriate (Clark, 2003; Schwartz and Trolle, 2010). Without going deep into the discussion about political and legal incentives to expropriate, these authors focus on the operational and market factors that may encourage the government to expropriate. Our paper forms a part of this literature. Modeling a government that expropriates the firm when cash flows are high, we study how the factors determining the value of the investment project affect the expropriation decision.

Second, we analyze how firms react to expropriation. There are two main options: (i) withdrawing all investment from the host country, and possibly making it return to autarky (e.g. Cole and English (1991); Schnitzer (2002); Guriev et al. (2011); Stroebel and van Benthem (2010)), and (ii) partially withdrawing investment, or underinvesting (Raff, 1992; Thomas and Worrall, 1994). In our model we observe a problem of underinvestment of the firm when there is a risk of expropriation. This happens because the firm invests too early and abandons too soon, compared with the case where there is no risk. To the best of our knowledge, there has been no reference in the literature to the possibility that firms have a smaller scope for losses (reflected in the abandonment decision) when the government creates a threat to expropriate its assets.

In the setting we propose, we are able to analyze how the firm's decisions interact with the probability of expropriation -and vice versa-, which is especially useful to answer the third question in our model: what are the costs of expropriation for the government and the overall economy in terms of reputation. Several authors consider that the government faces a reputation cost in terms of investment. Such costs are usually assumed to be exogenous (Schnitzer, 2002; Clark, 2003; Schwartz and Trolle, 2010). In our model, besides considering exogenous reputation costs, we go further to propose a loss/gain function for the government that allows to analyze the interaction between reputation costs and indemnity payments. This loss function accounts 
for the reaction of firms operating in the market and firms willing to enter, based on the idea that when one firm is threatened with expropriation all remaining investors will account for the risk of their assets being seized. We can do this thanks to the interaction between the indemnity payment, the probability of expropriation and the probability to shut down the project once the expropriation risk has been included in the firm's discount. Thus, our loss function makes the compensation offered upon expropriation contingent on reputation costs. With this, the government can derive the optimal policy in terms of indemnity payments to maximize its own gain from expropriation. We can also determine the optimal policy in terms of welfare, which is defined as the sum of value created by both the government and the firm. Notice that since the government is opportunistic, welfare is not one of its objectives. Therefore, the welfare maximizer policy is only a normative result.

The three questions above are studied in an economy with two types of businesses: essential and non-essential. Non-essential activities are those that, although creating value, are not necessary for the normal functioning of the economy. This special characteristic will be reflected in the decisions made by the government regarding expropriation. As far as we know, the problem of how different "social incentives" of the government affect the decision to expropriate and the investment decisions made by the firm, has not been analyzed yet. In terms of costs born by the government, the most similar case is posed by Raff (1992), who analyses the reaction of the government and the firm in a context of asymmetric information: the government only finds out after expropriation if it has expropriated the most costly firm to expropriate due to extra managerial skills that the owners of the firm withdraw from the country. However, our case does not assume asymmetric information.

The results of our model show that when the business is essential for the functioning of the economy, there is a greater welfare gain with a private, more efficient firm operating the project, than in the case where the business is not essential. Therefore, creating a threat to expropriate is also more costly in terms of welfare for essential businesses. This goes in line with results we obtain by endogenizing the reputation and indemnity costs: for essential activities, the government's optimal policy to maximize its gain is generally to expropriate the firm instead of confiscating: it is bound to offer a rather fair compensation, especially if the market is big. However, when the business is not essential, the government generally maximizes its gain by confiscating the firm or paying a low compensation whatever the size of the market.

In terms of welfare, however, whether the business is essential to the economy or not, the government should always pay the highest possible compensation to the firm. Since the offered indemnity has a negative relationship with the probability to expropriate, this implies that expropriation will always be suboptimal when it comes to total value creation in the economy.

\section{Assumptions}

The economy modeled is comprised of a government and private firms. We distinguish between firms already operating and firms that are considering realizing an initial investment (entrants).

The investment opportunity is identified by the use of the subscript 0 , while the values derived from operating businesses there will be no use of subscripts.

We consider two scenarios: a benchmark scenario, defined as the politically safe scenario, in which the government does not intervene in the economy beyond setting the fiscal regime. The second scenario represents the politically risky scenario in which an opportunistic government intervenes directly in the economy through expropriations. The risk scenarios are identified by the use of the superscript $j$, with $j=s, e$ representing a safe political environment and a risky environment, respectively.

Assumption 1. The government is an opportunistic agent. 
Cole and English (1991) argue that governments can expropriate out of either desperation or opportunism. The opportunistic behavior, which is the most common one, implies that expropriations are mere reactions of the government to high real prices of the product or service. In terms of our model, this implies that the government commits risky actions only when the cash flows of the project exceed a threshold, which we call expropriation trigger. When cash flows are below the trigger, the government does not take any action and commits to its tax schedule.

\section{Assumption 2. Political risk follows a continuous process.}

In our model, the government observes the level of cash flows and when it reaches a certain level, it engages in politically risky actions. This is in contrast to models such as those by Clark $(1997,2003)$, which define political risk as a Poisson process. This is suitable only in some cases in which expropriation is regulatory.

Assumption 3. The government distinguishes between essential and non-essential economic activities, and is committed with the operation of essential activities.

According to their economic activity, the government makes a distinction between essential and non-essential activities. The operation of essential economic activities can not be disrupted and must therefore be operated continuously either by a private investor or by the government. Non-essential sectors refer to sectors that may generate value for the economy once in operations but are not required for the normal functioning of an economy. These activities are only operated if it is profitable to do so: The government may follow a scheme to maximize the value of the project once it is operating and may abandon operations if the business is not profitable.

Essential sectors are those every country needs to have such as health-care, food-security, infrastructure, transports, etc. The essential nature of these activities does not imply the existence of an altruistic government: opportunism may cause to operate a loss making essential business in order to perpetuate itself in power ${ }^{5}$. The economic sectors are identified by the use of the superscript $i$, in which $i=u, c$ representing the essential and non-essential businesses, respectively.

Assumption 4. The objective of the private firm is to maximize shareholder value.

For the private firm operating in a safe political environment, there is no difference between any of the sectors, since it does not bear any social responsibilities, and can abandon the project if it is no longer profitable.

Assumption 5. The government commits to a tax scheme that the firm must comply with.

In the general case, the government's income comprises corporate taxes. In some cases, however, depending on the type of activity, it may also charge royalties, which are usually charged over public assets and when legislation determines a sovereign ownership of natural resources regardless of them being located in privately owned land (Rigobon, 2010; Postali, 2009).

Assumption 6. The firm has no outside opportunities.

Assumption 7. Neither the government nor the private firm are financially constrained.

\footnotetext{
${ }^{5}$ In the case of democratic regimes, disruption to the essential sectors may trigger changes in the governing party in the following elections and may generate costs for the revenues of the government through: (i) costs associated with reduced investor confidence in the country and capital flight (Le and Zak, 2006; Lensink et al., 2000), and (ii) reductions in productivity if social unrest materializes in strikes and protests (Renn et al., 2011). In the case of autocratic regimes, although there are no political cycles pressing the current governing party, there is a real fear of regime change through social unrest.
} 
Assumption 8. There are no informational asymmetries.

Both the government and the private firm know all the relevant information and rationally anticipate each other's reaction.

Assumption 9. The government is less cost-efficient than the private firm.

It may not be the rule, but the conception is that private firms are more efficient than public enterprises. Even though in many cases these public enterprises are engaged in activities that are not directly comparable with those of private firms, there are certain organizational features that can be considered as the source of government inefficiency. It can come as a result of transferring resources to actors that provide political support to the government (Shleifer, 1998; Megginson, 2005), or even due to the fact that these enterprises are not profit oriented, which may lead them to disregard productivity maximization as an objective (Stiglitz, 2000).

Assumption 10. The project has uncertain cash flows, x, represented by a Geometric Brownian motion

$$
d x=\mu x d t+\sigma x d z
$$

where $\mu$ is the instantaneous growth rate of cash flows, $\sigma$ their standard deviation, and $d z$ is the increment of a standard Wiener process. We also assume that $\mu<r$, being $r$ the constant and known interest rate, so that we are able to obtain finite solutions. We denote the return shortfall, $r-\mu$, by $\delta$.

For both agents considered, the government and the private investor, we determine the values of an investment opportunity $\left(G_{0}(x), V_{0}(x)\right)$ and an operating business $(G(x), V(x))$. For the sake of conciseness we briefly describe the value of a general claim $A$ in which $A=G, V$ for the cases of government and private investor, respectively. The following Ordinary Differential Equations - ODEs- describe the value of this general claim in terms of the investment opportunity $A_{0}$ and operating business $A$.

$$
\begin{gathered}
0.5 \sigma^{2} x^{2} A_{0 x x}+\mu x A_{0 x}-r A_{0}=0 \\
0.5 \sigma^{2} x^{2} A_{x x}+\mu x A_{x}-r A+\pi=0
\end{gathered}
$$

where $\pi=a x+b$ (Table 1 ) represents the cash flows accruing to each claim. They comprehend a variable component associated with the behavior of cash flows, $a x$, and a fixed component, $b$, independent of $x$. Table 1 defines $a$ and $b$. Remember that according to Assumption 5, the government has a scheme tax, to which it is committed and the firm must comply with it. This scheme consists of a corporate income tax, $\tau$, and a royalty fee, $\rho$, that may be applied on its gross revenue. Therefore, when the firm operates the project, $a x+b$ is the after tax revenue in the value equation $V^{j}(x)$, and the fiscal revenue in the government's valuation of the project, $G^{i j}(x)$. The fixed component is related with the operating costs of the project, $c_{v}$ if it is operated by the private firm, and $c_{g}$ if it is operated by the government. Note that the basic difference between equations 2 and 3 is that the first one is a homogeneous $\operatorname{ODE}(\pi=0)$, since it values an option to invest, which does not generate any income.

Table 1: Specification of the ODE

\begin{tabular}{ccl}
\hline$A(x)$ & $a$ & $b$ \\
\hline$G^{i}(x)$ & 1 & $-c_{g}$ \\
$V^{j}(x)$ & $(1-\rho)(1-\tau)$ & $-c_{v}(1-\tau)$ \\
$G^{i j}(x)$ & $(1-\rho) \tau+\rho$ & $-c_{v} \tau$
\end{tabular}


The general solution to both ODEs are, respectively:

$$
\begin{gathered}
A_{0}^{j}(x)=B_{1} x^{\beta_{1}}+B_{2} x^{\beta_{2}}, \\
A^{j}(x)=\frac{a x}{\delta}+\frac{b}{r}+B_{3} x^{\beta_{1}}+B_{4} x^{\beta_{2}},
\end{gathered}
$$

with $a$ and $b$ as given in Table 1 , and

$$
\begin{aligned}
& \beta_{1}=\frac{1}{2}-\frac{\mu}{\sigma^{2}}+\sqrt{\left(\frac{1}{2}-\frac{\mu}{\sigma^{2}}\right)^{2}+\frac{2 r}{\sigma^{2}}}>1 \\
& \beta_{2}=\frac{1}{2}-\frac{\mu}{\sigma^{2}}-\sqrt{\left(\frac{1}{2}-\frac{\mu}{\sigma^{2}}\right)^{2}+\frac{2 r}{\sigma^{2}}}<0
\end{aligned}
$$

$\beta_{1}$ and $\beta_{2}$ are the roots to the following characteristic polynomial

$$
\left(0.5 \beta^{2} \sigma^{2}+\beta\left(\mu-0.5 \sigma^{2}\right)-r\right) x^{\beta}=0
$$

$B_{j}$ are constants to be determined given appropriate boundary conditions. For the investment opportunity, zero is an absorbing barrier for the process: no prospect of profit in the future makes the asset worth nothing. Thus, $V(0)=0$. However, since $\beta_{2}<0$, as $x$ goes to zero, the value function would go to infinity. So, $B_{2}$ is set equal to zero in order to prevent that from happening. In the case of operations in a safe environment ${ }^{6}(j=s), B_{3}$ is also equal to zero. This comes from imposing the condition below (9), which simply means that when the cash flows are considerably high, the project will never be abandoned.

$$
\lim _{x \rightarrow \infty}=\frac{a}{\delta} x+\frac{b}{r}
$$

\section{The benchmark cases}

This paper considers two benchmark cases: public provision and private provision in a political safe environment. In the first benchmark both the realization of the initial investment and actual operations are solely responsibility of the government; in this benchmark there is no private participation. The second benchmark considers a private firm that realizes the investment and operates a business following a value maximization scheme, regardless of the type of business considered; the government merely regulates the economic environment in which the firm operates. The government receives taxes and may receive royalties depending on the type of business.

\subsection{Public provision}

The importance of analyzing public provision is two fold, firstly, it represents the dynamics of the value of the business once it is operated by the government when the private investors abandon or whenever the government decides to expropriate it. Secondly, it provides the benchmark to assess the value of private participation in the economy.

The following proposition summarizes the value generated to the government in the essential and non-essential sectors.

Proposition 1. Public provision of operating businesses

The value of a business operated by a government in the essential sector is defined as $G^{u}(x)$ and its value is given by,

$$
G^{u}(x)=\frac{x}{\delta}-\frac{c_{g}}{r} .
$$

\footnotetext{
${ }^{6}$ As we will show later, for the case of expropriation risk, this condition is dropped
} 
The value of a business operated by a government in the non-essential sector is defined as $G^{c}(x)$ and for $x>x_{a}$ its value is given by,

$$
G^{c}(x)=\frac{x}{\delta}-\frac{c_{g}}{r}-\left(\frac{x_{a}}{\delta}-\frac{c_{g}}{r}\right)\left(\frac{x}{x_{a}}\right)^{\beta_{2}}
$$

in which $x_{a}$ represents the abandonment trigger and is given by,

$$
x_{a}=\frac{\beta_{2}}{\beta_{2}-1} \frac{\delta c_{g}}{r} .
$$

Notice the extra term in the equation for the government value in a non-essential project. It represents the value of the abandonment option, which does not exist if the project is essential. Since an abandonment option gives the opportunity to stop losses, it will add value to the project, and therefore this term will be positive. The implication of this is that the operating value of a non-essential business is higher than the operating value of an essential business.

Before investments are realized, the value for the government represents the value of an investment opportunity that is summarized in the following proposition.

Proposition 2. Public provision before investment is realized

The value of an investment opportunity for a government in an essential business is defined as $G_{0}^{u}$ and for $x<x_{I}^{u}$ its value is given by,

$$
G_{0}^{u}(x)=\left(\frac{x_{I}^{u}}{\delta}-\frac{c_{g}}{r}-I_{g}\right)\left(\frac{x}{x_{I}^{u}}\right)^{\beta_{1}}
$$

in which $x_{I}^{u}$ represents the investment trigger and it is determined as,

$$
x_{I}^{u}=\frac{\beta_{1}}{\beta_{1}-1}\left(\frac{\delta c_{g}}{r}+I_{g}\right) .
$$

The value of an investment opportunity for a government in a non-essential business is defined as $G_{0}^{c}(x)$ and for $x<x_{I}^{c}$ its value is given by,

$$
G_{0}^{c}(x)=\left(\frac{x_{I}^{c}}{\delta}-\frac{c_{g}}{r}-\left(\frac{x_{a}}{\delta}-\frac{c_{g}}{r}\right)\left(\frac{x_{I}^{c}}{x_{a}}\right)^{\beta_{2}}-I_{g}\right)\left(\frac{x}{x_{I}^{c}}\right)^{\beta_{1}}
$$

in which the abandonment trigger $x_{a}$ is given by equation (12), and the investment trigger $x_{I}^{c}$ is numerically determined from the following implicit equation,

$$
\left(\beta_{1}-1\right) \frac{x_{I}^{c}}{\delta}-\left(\frac{c_{g}}{r}+I_{g}\right) \beta_{1}-\left(\beta_{1}-\beta_{2}\right)\left(\frac{x_{a}}{\delta}-\frac{c_{g}}{r}\right)\left(\frac{x_{I}^{c}}{x_{a}}\right)^{\beta_{2}}=0 .
$$

Given the fact that the operating value is higher for a non-essential activity than for an essential one, the investment trigger for a non-essential business will also naturally be lower. An essential business needs to be operated regardless of the cash flow levels (implying it may be operated with losses), therefore it is important to be more prudent when investing in essential businesses, which in this case can be expressed as requiring a higher initial cash-low level before undertaking the investment. Investment mistakes are more costly with essential businesses due to the fact that they cannot be abandoned. It is important for public planners to bear in mind that they pursue welfare maximizing objectives, because a government acting as a value maximizer could be tempted to prioritize investments in non-essential businesses and possibly neglect investments that are essential to the economy. 


\subsection{Private provision in a safe political environment}

This set-up allows assessing the impact of the different sources of political risk analyzed and allows determining the different costs of political risk considered. We start by stating the value accruing for the private firm and for the government once the business is operating are given in proposition 3. We assume that the government imposes a tax scheme to the firm that is held as long as the firm is on operations: the firm's cash inflows are subject to a corporate income tax, $\tau$, and to royalties, $\rho$. Therefore the terms $(1-\rho)$ and $(1-\tau)$ represent the proportion of after tax cash inflows of the firm. While most firms are subject to corporate income taxes, royalties are only applied to certain types of economic activities. They can be considered a special fiscal regime that arises from the fact that these resources are typically owned by national states who lease production to private corporations, and this gives them the right to grab resource rents ${ }^{7}$ (Postali, 2009; Rigobon, 2010). Examples of activities requiring royalty payments are typically oil, gas and mining activities; in some countries, forestry is also subject to royalty fees.

Proposition 3. Operating values when there is private provision in a safe political environment The value of an operating firm for a private investor regardless of the type of business is defined as $V^{s}(x)$ and for $x>x_{a}^{s}$ its value is given by,

$$
V^{s}(x)=\left(\frac{x}{\delta}(1-\rho)-\frac{c_{v}}{r}\right)(1-\tau)-\left(\frac{x_{a}^{s}}{\delta}(1-\rho)-\frac{c_{v}}{r}\right)\left(\frac{x}{x_{a}^{s}}\right)^{\beta_{2}}(1-\tau)
$$

in which the abandonment trigger $x_{a}^{s}$ is given by,

$$
x_{a}^{s}=\frac{\beta_{2}}{\beta_{2}-1} \frac{\delta c_{v}}{r(1-\rho)} .
$$

The value for the government if it is an essential business is defined as $G^{u s}(x)$ and for $x>x_{a}^{s}$ its value is given by,

$$
\begin{array}{r}
G^{u s}(x)=\frac{x}{\delta} \rho+\left(\frac{x}{\delta}(1-\rho)-\frac{c_{v}}{r}\right) \tau \\
+\left(\frac{x_{a}^{s}}{\delta}(1-\rho)(1-\tau)+\frac{c_{v} \tau}{r}-\frac{c_{g}}{r}\right)\left(\frac{x}{x_{a}^{s}}\right)^{\beta_{2}} .
\end{array}
$$

The value for the government if it is a non-essential business is defined as $G^{c s}(x)$ and for $\frac{c_{v}}{c_{g}}>1-\rho \Rightarrow x_{a}<x_{a}^{s}$ the value of $G^{c s}(x)$ is given by,

$$
\begin{array}{r}
G^{c s}(x)=\frac{x}{\delta} \rho+\left(\frac{x}{\delta}(1-\rho)-\frac{c_{v}}{r}\right) \tau \\
+\left(\frac{x_{a}^{s}}{\delta}(1-\rho)(1-\tau)+\frac{c_{v} \tau}{r}-\frac{c_{g}}{r}-\left(\frac{x_{a}}{\delta}-\frac{c_{g}}{r}\right)\left(\frac{x_{a}^{s}}{x_{a}}\right)^{\beta_{2}}\right)\left(\frac{x}{x_{a}^{s}}\right)^{\beta_{2}}
\end{array}
$$

in which the abandonment trigger for the government $x_{a}$ is given by equation (12).

For $\frac{c_{v}}{c_{g}}<1-\rho \Rightarrow x_{a}>x_{a}^{s}$ the value of $G^{c s}(x)$ is given by,

$$
G^{c s}(x)=\frac{x}{\delta} \rho+\left(\frac{x}{\delta}(1-\rho)-\frac{c_{v}}{r}\right) \tau-\left(\frac{x_{a}^{s}}{\delta}(\rho+(1-\rho) \tau)-\frac{c_{v} \tau}{r}\right)\left(\frac{x}{x_{a}^{s}}\right)^{\beta_{2}}
$$

\footnotetext{
${ }^{7}$ However, there are some cases in which the royalties belong to the private owner of the land. For instance, in the U.S. private owners are allowed to have mineral rights.
} 
The second terms of equations 17, and 19 to 21 are related with the abandonment option of the firm. In eq. 17 this term represents the value of the option to the firm, and it will always non-negative because it adds value to the project. As for the government equations, the second term can be interpreted as the government's valuation of the firm's abandonment option. There are some differences in this term, depending on the case. For an essential activity (eq. 19), the term will most likely be below zero ${ }^{8}$, because if the firm abandons the government must keep operations, disregarding the level of profitability. If the project is essential and the government's abandonment trigger is smaller than the firm's $\left(x_{a}<x_{a}^{s}\right)$, then it will continue operating the project, and the second term in eq. 20 accounts for the foregone fiscal revenue and for the value of its very own abandonment option. Finally, if the government's abandonment trigger is above the firm's trigger, then the valuation of the abandonment option captures the expected loss of fiscal revenue from firm's abandonment.

Before investments are realized, the value of the investment opportunity accruing to the private investor and the government is summarized in the following proposition.

Proposition 4. Option values when there is private provision in a safe political environment The value of an investment opportunity for a private firm regardless of the type of business is defined as $V_{0}^{s}(x)$ and its value is given by,

$$
\begin{gathered}
V_{0}^{s}(x)=\left(\left(\frac{x_{I}^{s}}{\delta}(1-\rho)-\frac{c_{v}}{r}\right)(1-\tau)\right)\left(\frac{x}{x_{I}^{s}}\right)^{\beta_{1}} \\
-\left(\left(\frac{x_{a}^{s}}{\delta}(1-\rho)-\frac{c_{v}}{r}\right)\left(\frac{x_{I}^{s}}{x_{a}^{s}}\right)^{\beta_{2}}(1-\tau)-I_{v}\right)\left(\frac{x}{x_{I}^{s}}\right)^{\beta_{1}}
\end{gathered}
$$

in which the abandonment trigger $x_{a}^{s}$ is given by equation (18), and the investment trigger $x_{I}^{s}$ is numerically determined from the following implicit equation,

$$
\begin{gathered}
\left(\beta_{1}-1\right) \frac{(1-\rho)(1-\tau)}{\delta} x_{I}^{s}-\beta_{1}\left(\frac{c_{v}(1-\tau)}{r}+I_{v}\right) \\
-\left(\beta_{1}-\beta_{2}\right)(1-\tau)\left(\frac{x_{a}^{s}}{\delta}(1-\rho)-\frac{c_{v}}{r}\right)\left(\frac{x_{I}^{s}}{x_{a}^{s}}\right)^{\beta_{2}}=0
\end{gathered}
$$

The value of such an investment opportunity for the government in an essential business is defined as $G_{0}^{u s}(x)$ and its value is given by,

$$
\begin{gathered}
G_{0}^{u s}(x)=\left(\frac{x_{I}^{s}}{\delta} \rho+\left(\frac{x_{I}^{s}}{\delta}(1-\rho)-\frac{c_{v}}{r}\right) \tau\right)\left(\frac{x}{x_{I}^{s}}\right)^{\beta_{1}} \\
+\left(\left(\frac{x_{a}^{s}}{\delta}(1-\rho)(1-\tau)+\frac{c_{v} \tau}{r}-\frac{c_{g}}{r}\right)\left(\frac{x_{I}^{s}}{x_{a}^{s}}\right)^{\beta_{2}}\right)\left(\frac{x}{x_{I}^{s}}\right)^{\beta_{1}}
\end{gathered}
$$

The value of this investment opportunity for the government in a non-essential business is defined as $G_{0}^{c s}(x)$ and for $\frac{c_{v}}{c_{g}}>1-\rho \Rightarrow x_{a}<x_{a}^{s}$ its value is given by,

$$
\begin{array}{r}
G_{0}^{c s}(x)=\left(\frac{x_{I}^{s}}{\delta} \rho+\left(\frac{x_{I}^{s}}{\delta}(1-\rho)-\frac{c_{v}}{r}\right) \tau\right)\left(\frac{x}{x_{I}^{s}}\right)^{\beta_{1}}+ \\
\left(\left(\frac{x_{a}^{s}}{\delta}(1-\rho)(1-\tau)+\frac{c_{v} \tau}{r}-\frac{c_{g}}{r}-\left(\frac{x_{a}}{\delta}-\frac{c_{g}}{r}\right)\left(\frac{x_{a}^{s}}{x_{a}}\right)^{\beta_{2}}\right)\left(\frac{x_{I}^{s}}{x_{a}^{s}}\right)^{\beta_{2}}\right)\left(\frac{x}{x_{I}^{s}}\right)^{\beta_{1}}
\end{array}
$$

in which the abandonment trigger for the government $x_{a}$ is given by equation (12). The value of this investment opportunity for the government if the economic sector is commodities for the

\footnotetext{
${ }^{8}$ It may be positive if the private is very inefficient compared to the government or if the level of royalties generates a large distortion in the abandonment decision of the firm
} 


$$
\begin{aligned}
& \text { case } \frac{c_{v}}{c_{g}}<1-\rho \Rightarrow x_{a}>x_{a}^{s} \text { is } \\
& \begin{array}{c}
G_{0}^{c s}(x)=\left(\frac{x_{I}^{s}}{\delta} \rho+\left(\frac{x_{I}^{s}}{\delta}(1-\rho)-\frac{c_{v}}{r}\right) \tau\right)\left(\frac{x}{x_{I}^{s}}\right)^{\beta_{1}} \\
-\left(\left(\frac{x_{a}^{s}}{\delta}(\rho+(1-\rho) \tau)-\frac{c_{v} \tau}{r}\right)\left(\frac{x_{I}^{s}}{x_{a}^{s}}\right)^{\beta_{2}}\right)\left(\frac{x}{x_{I}^{s}}\right)^{\beta_{1}}
\end{array}
\end{aligned}
$$

\section{Numerical results: base case and comparative statics}

The following table presents the operating values $\left(V^{S}, G^{c}\right.$ and $\left.G^{u}\right)$, option values $\left(V_{0}^{S}, G_{0}^{c}\right.$ and $\left.G_{0}^{u}\right)$ and abandonment $\left(x_{a}^{s}\right)$ and investment $\left(x_{I}^{s}\right)$ triggers when investment is realized by a private investor in a safe political environment. For the base case parameters we assume figures aimed at generating a typical business. The initial cash flow level $\left(x_{0}\right)$ is 1 , its growth rate $(\mu)$ is $1 \%$ (following Gorbenko and Strebulaev $(2010)$ ) and its volatility $(\sigma)$ is $25 \%$ (following Eom et al. (2004)). The corporate tax rate is $15 \%$, the royalties are assumed to be $0 \%$ and the private investor is assumed to be more efficient than the government in terms of the operating costs $\left(c_{v}=0.4\right.$ vs $\left.c_{g}=0.6\right)$ but equally efficient in terms of the investment $\operatorname{costs}\left(I_{v}=I_{g}=20\right)$. Finally, the risk free interest rate $(r)$ is $6 \%$.

Table 2 presents the results for the base case and the dynamics of the comparative statics. The results in the base case show that the value of the government when the firm is operating a non-essential project is larger than when the project is essential. As mentioned before, this is due to the fact that the government does not have the possibility to decide whether to continue operating a project in the essential sector once the firm shuts it down. Besides, for this base case parameters, we can also see that the firm's abandonment trigger is lower than the government's trigger for a non-essential business, because we assume that it is operationally more efficient, and royalties are equal to zero (see Proposition 1).

As it can be seen in table 2 , increases in the growth rate of the cash flows $(\mu)$, decreases in the risk free rate $(r)$ and decreases in the operating costs of the private investor $\left(c_{v}\right)$ are all associated with increases in the value of the operating business and in the value of the investment opportunity for both the government and the private investor. An increase in volatility $(\sigma)$ increases the value of the operating business for the firm, and for the government, if the activity is non essential. This is because if the activity is essential, the government only partially benefits from potential increases in $x$ through the taxes collected, and bears the negative effects of decreases in $x$, because it is forced to operate the business following the abandonment of the private investor. The value of the investment opportunity is increasing in $\sigma$ for all the agents.

Changes in royalties $(\rho)$ and taxes $(\tau)$ modify the distribution of value between the government and the private investor, in which increases in $\tau$ or in $\rho$ increase the value accruing for the government and reduce the value accruing for the private investor, regardless of the type of business and regardless if the business is already operating or is still an investment opportunity. However, the results show a Laffer curve for royalties: the value of the government increases only up to a certain point when we vary $\rho$, meaning that there is a point in which governments start losing revenue as a result of rising royalty rates. The fact that we don't observe a Laffer curve for corporate income tax has to do with the fact that abandonment is neutral to taxes.

In terms of the decisions to invest and to abandon we observe that whenever a change in a parameter value translates into an increase in the operating value of the business, abandonment occurs later (decrease in $x_{a}$ ) and investment occurs earlier (decrease in $x_{I}$ ). The exception comes with higher volatility $(\sigma)$, which by increasing the value of both options, delays the exercise of investment and abandonment. The other exception relates with the neutral nature of the tax system regarding the abandonment decision, since the tax system is assumed to be symmetrical 
Table 2: Private provision: operating and option values, abandonment and investment triggers

\begin{tabular}{l|rrrrrrrrr}
\hline Parameters & $x_{a}^{s}$ & $V^{s}(x)$ & $G^{s u}(x)$ & $x_{a}$ & $G^{s c}(x)$ & $x_{I}^{s}$ & $V_{0}^{s}(x)$ & $G_{0}^{s u}(x)$ & $G_{0}^{s c}(x)$ \\
\hline Base case & 0.1736 & 11.738 & 1.098 & 0.26 & 2.071 & 3.4559 & 3.711 & 1.021 & 1.05 \\
\hline$\mu=0$ & 0.1973 & 9.092 & 0.221 & 0.296 & 1.604 & 3.6376 & 2.037 & 0.605 & 0.636 \\
$\mu=0.025$ & 0.1314 & 18.8 & 2.861 & 0.197 & 3.318 & 3.2076 & 9.214 & 2.23 & 2.248 \\
$\mu=0.05$ & 0.0421 & 79.342 & 13.976 & 0.063 & 14.002 & 2.8661 & 67.178 & 12.942 & 12.943 \\
\hline$r=0.02$ & 0.0692 & 70.705 & 6.862 & 0.104 & 12.477 & 2.3472 & 58.529 & 10.313 & 11.587 \\
$r=0.1$ & 0.2149 & 6.185 & 0.721 & 0.322 & 1.091 & 4.6071 & 0.742 & 0.26 & 0.261 \\
$r=0.14$ & 0.239 & 4.175 & 0.552 & 0.358 & 0.737 & 5.7409 & 0.197 & 0.081 & 0.081 \\
\hline$\sigma=0.05$ & 0.3061 & 11.333 & 2 & 0.459 & 2 & 1.9726 & 0.435 & 0.272 & 0.272 \\
$\sigma=0.45$ & 0.1021 & 12.769 & -0.653 & 0.153 & 2.253 & 5.7128 & 6.948 & 1.436 & 1.566 \\
$\sigma=0.65$ & 0.0642 & 13.711 & -2.109 & 0.096 & 2.42 & 8.7868 & 9.4 & 1.721 & 1.924 \\
\hline$\rho=0.12$ & 0.1973 & 9.759 & 3.003 & 0.26 & 4.041 & 3.9271 & 2.961 & 1.656 & 1.677 \\
$\rho=0.24$ & 0.2284 & 7.799 & 4.864 & 0.26 & 5.956 & 4.5472 & 2.285 & 2.132 & 2.146 \\
$\rho=0.36$ & 0.2712 & 5.871 & 6.655 & 0.26 & 7.765 & 5.3998 & 1.687 & 2.44 & 2.449 \\
\hline$\tau=0.05$ & 0.1736 & 13.119 & -0.283 & 0.26 & 0.69 & 3.1682 & 4.432 & 0.334 & 0.37 \\
$\tau=0.3$ & 0.1736 & 9.667 & 3.169 & 0.26 & 4.143 & 4.0404 & 2.713 & 1.872 & 1.89 \\
$\tau=0.4$ & 0.1736 & 8.286 & 4.55 & 0.26 & 5.524 & 4.5915 & 2.109 & 2.296 & 2.308 \\
\hline$c_{v}=0.2$ & 0.0868 & 14.262 & 1.937 & 0.26 & 2.517 & 3.0888 & 4.05 & 1.173 & 1.196 \\
$c_{v}=0.6$ & 0.2604 & 9.444 & 0.556 & 0.26 & 1.667 & 3.8147 & 3.434 & 0.913 & 0.937 \\
$c_{v}=1$ & 0.434 & 5.574 & 0.451 & 0.26 & 1.561 & 4.5144 & 3.007 & 0.769 & 0.777 \\
\hline$c_{g}=0.2$ & 0.1736 & 11.738 & 2.092 & 0.087 & 2.204 & 3.4559 & 3.711 & 1.05 & 1.05 \\
$c_{g}=0.4$ & 0.1736 & 11.738 & 1.595 & 0.174 & 2.071 & 3.4559 & 3.711 & 1.036 & 1.05 \\
$c_{g}=1$ & 0.1736 & 11.738 & 0.104 & 0.434 & 2.071 & 3.4559 & 3.711 & 0.992 & 1.05 \\
\hline$I_{v}=15$ & 0.1736 & 11.738 & 1.098 & 0.26 & 2.071 & 2.7719 & 4.39 & 1.159 & 1.212 \\
$I_{v}=25$ & 0.1736 & 11.738 & 1.098 & 0.26 & 2.071 & 4.1377 & 3.234 & 0.913 & 0.93 \\
$I_{v}=30$ & 0.1736 & 11.738 & 1.098 & 0.26 & 2.071 & 4.8183 & 2.879 & 0.826 & 0.837 \\
\hline
\end{tabular}

Notes: This table presents the operating values $\left(V^{s}, G^{s u}\right.$ and $\left.G^{s c}\right)$, option values $\left(V_{0}^{s}, G_{0}^{s u}\right.$ and $\left.G_{0}^{s c}\right)$ and abandonment $\left(x_{a}^{s}\right)$ and investment $\left(x_{I}^{s}\right)$ triggers. The base-case parameter values are as follows: the initial cash flow level $x_{0}$ is 1 , the growth rate of cash flows $(\mu)$ is $1 \%$, the volatility of cash flows $(\sigma)$ is $25 \%$, the operating costs for the private firm $\left(c_{v}\right)$ are 0.4 , the operating costs for the government $\left(c_{g}\right)$ are 0.6 , the risk free rate $(r)$ is $6 \%$ and the investment cost $\left(I_{v}\right)$ is 20 .

an increase in taxes is associated with a decrease in the operating value for the private investors, but this does not translate into an earlier abandonment $\left(x_{a}\right.$ does not change with changes in $\left.\tau\right)$.

We have analyzed how changes in the base case parameters affect the decisions of the private investor and the government in terms of investment and abandonment and also how it affects the value of these individual claims. Now we consider additional measures that allow us to understand how private participation affects other aspects such as investment timing, investment volumes, costs for the government of allowing private participation and the welfare impact of private participation.

\subsection{Investment, public and welfare effects of private provision}

Investment timing: In terms of investment timing we analyze how changes affect the expected time in which the investment is realized. We define the expected time to investment as $\theta$ and we know (Pennings, 2000) that the expected time to investment can be determined as

$$
\theta=\frac{\ln \left(x_{0}\right)-\ln \left(x_{I}\right)}{\mu-0.5 \sigma^{2}} .
$$

Since we are concerned about the changes in the investment timing induced by private pro- 
vision we express our measure of timing as follows

$$
\Theta^{s}=\frac{\theta^{v}-\theta^{g}}{\theta^{g}}=\frac{\ln \left(x_{I}^{g}\right)-\ln \left(x_{I}^{s}\right)}{\ln \left(x_{0}\right)-\ln \left(x_{I}^{g}\right)} .
$$

If $\Theta^{s}<0$, private provision accelerates the realization of investments relative to public provision, otherwise investments are delayed.

Change in project's value This measures allows for determining if the private operation of the project implies a better result in terms of project value.

$$
H^{s}=V^{s}\left(x_{0}\right) / G\left(x_{0}\right)-1 .
$$

Cost for the government: The cost for the government regarding an individual firm represents the difference between having private and public provision, we define this cost as $\Gamma$ for an operating business and it is expressed as,

$$
\Gamma^{s}=G^{s}\left(x_{0}\right)-G\left(x_{0}\right),
$$

the cost for an individual investment opportunity we define this cost as $\Gamma_{0}$ :,

$$
\Gamma_{0}^{s}=G_{0}^{s}\left(x_{0}\right)-G_{0}\left(x_{0}\right) .
$$

In most cases, there is an obvious opportunity cost for the government by 'allowing' private firms to operate profitable businesses, because the government forgoes the entire earnings the business generates in exchange of reduced tax revenues and/or royalties. However, the cost for the government should not be the most important driver of public decisions, because different aspects justify the importance of private investors such as:

- An increase in the overall level of investments, because the government may redeploy its resources to other activities

- Allowing governments to focus on their core activities that do not imply making profits

- Creating less distortions on the economy by having the government competing with private enterprises (double role of the government)

- Reducing the governmental budgets or budget deficits

Social Welfare: We define social welfare as the overall value created by a business. We consider this an aspect that should be high on the public agenda to support the decision making process. Our measure of social welfare for an individual operating business is given by

$$
\Omega^{s}=\left(V^{s}(x)+G^{s}(x)\right)-G(x)
$$

and the social welfare for an investment opportunity is

$$
\Omega_{s 0}=\left(V_{0}^{s}(x)+G_{0}^{s}(x)\right)-G_{0}(x)
$$

Altruistic governments that have as objective the maximization of welfare would focus on $\Omega$. In turn, an opportunistic government would focus on $\Gamma$. 


\section{Numerical results}

Table 3 presents the effects of private provision in terms of investment timing $\left(\Theta^{s}\right)$, investment volume $\left(H^{s}\right)$, governmental costs and social welfare. The base case parameter values are the same s used in section 3.1. The results show that the overall benefits of private provision in terms of timing (decrease in $\Theta^{s}$ ), investment volumes (increase in $H^{s}$ ) and welfare (increases in $\Omega^{s}$ and in $\Omega_{0}^{s}$ ) are largely associated with relative private efficiency and with a reduction in the distortions introduced by taxes and royalties.

The existence of a more efficient private investor $\left(c_{v}<c_{g}\right.$ or $\left.I_{v}<I_{g}\right)$ leads to accelerated investments, higher investment volumes and increased welfare and in most cases it also reduces the government opportunity costs $\left(\Gamma^{s}\right.$ and $\left.\Gamma_{0}^{s}\right)$. The relative importance of private efficiency is also clear when we compare the effects of increases in the growth rate of the cash flows $(\mu)$ with decreases in interest rates $(r)$. In both cases, and regardless of the nature of the investment, businesses are more valuable (operating and in still in project), investments are accelerated, investors are willing to commit to higher investments and welfare is increased. However, with increases in $\mu$, the benefits of having more efficient private investors are diluted, because only the present value of the cash-in-flows is increased and the value of higher operational efficiency is reduced. With decreases in $r$, both the cash-in and cash-out flows are affected by the changes in $r$ and differences in operating efficiency still remain important. This explains why the benefits of private provision in terms of welfare (increase in $\Omega^{s}$ and in $\Omega_{0}^{s}$ ) are significant when $r$ decreases and the same benefits are merely modest when $\mu$ increases. The same logic also explains the higher benefits of private provision in terms of investment timing $\left(\Theta^{s}\right)$ and investment volumes $\left(H^{s}\right)$ for low $r$ compared with high $\mu$. This leads to conclude that whenever private investors are more efficient than a government, it is more important for a government to stimulate private investment in a context of low interest rates than in a context of fast growth.

The existence of corporate taxes and royalties distorts the behavior of private investors in terms of investments and abandonment decisions (royalties only in this case). For operating businesses there is tax neutrality because the tax system is symmetrical and the government participates in the gains and losses of the firm proportionally. In terms of royalties, they are collected whether the firm presents gains or losses and therefore abandonment is not neutral to royalties (see expression 18). Even though a more efficient firm $\left(c_{v} / c_{g}<1\right)$ is expected to abandon later than a government, royalties may change this as reflected in eq. 20. With high royalties, following private abandonment $x<x_{a}^{s}$ the government operates the business while $x>x_{a}$, because the private abandonment was inefficient due to high royalties $\left(c_{v} / c_{g}<\right.$ $1-\rho$ ). Unfortunately, as Rigobon (2010) points out, politicians tend to favour royalties over taxes, although the distortions introduced by royalties are well known in the existing literature. Bergstrom (1984)[p.177] argues that royalties change the production plans of firms. For the case of mining activities "a system of royalties (...) is inefficient because it will induce mining companies to discontinue operations on mines before it is economically appropriate to do so and will inhibit the development of marginally efficient mines". It is not surprising that a reduction in $\tau$ or in $\rho$ is associated with accelerated investments (lower $\Theta^{s}$ ) higher investment volumes (higher $H^{s}$ ) and increased welfare (higher $\Omega^{s}$ and $\Omega_{0}^{s}$ in the case of royalties and higher $\Omega_{0}^{s}$ in the case of taxes). However, since tax and royalties represent the income of the government, reductions $\tau$ and in $\rho$ are associated with important increases in the governmental opportunity costs (decreases in $\Gamma^{s}$ and in $\Gamma_{0}^{s}$ ).

Overall, the benefits of private provision are more significant in the case of essential businesses. The difference in welfare is calculated as $\Delta \Omega_{0}^{s}=\Omega_{0}^{s u}-\Omega_{0}^{s c}$ for investment opportunities, and $\Delta \Omega^{s}=\Omega^{s u}-\Omega^{s c}$ for operating business. In terms of investment opportunities $\left(\Omega_{0}^{s}\right)$ the benefits for essential businesses tend to outweigh the benefits of non-essential businesses apart from the following cases: high $I_{g}$, low $I_{v}$, high $c_{g}$, low $\tau$ and low $r$. In all these cases private provision accelerates investments significantly relative to public provision, therefore increasing the 
probability that the government may have to operate the business following the abandonment of private investors. For operating businesses, the economy also experiences a higher welfare gain with the private's entry in essential activities. This can be explained by the fact that in these activities the government doesn't have the option to abandon the project, even if it's operating at a loss. In general, reduction in the value of the abandonment option for the government will reduce the difference in welfare between sectors (higher $\mu$, and lower $r$ and $\sigma$ ). However there are some exceptional cases in which operations by the private generate the same social welfare in both sectors. This happens when $x_{a}<x_{a}^{s}$; that is, when $c_{v} / c_{g}>1-\rho$. Therefore, the difference in welfare also depends on the relative efficiency of the private with respect to the government and of how distorting royalties are for the abandonment decision. In the case of taxes, the difference in welfare is constant, since they are symmetric, and don't have any effect on either of the abandonment options. 


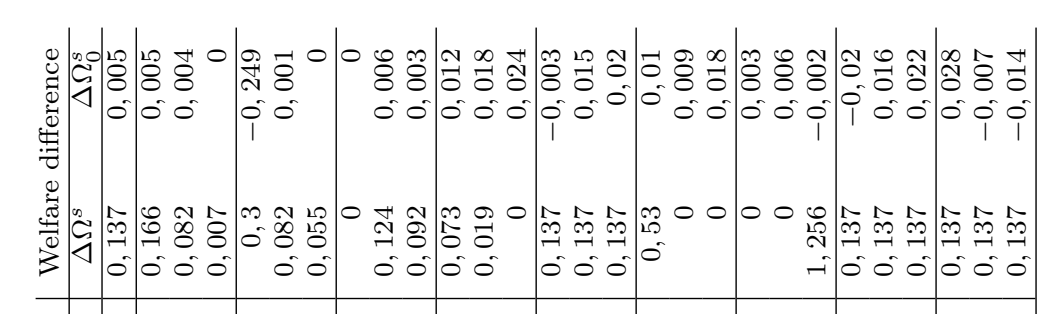

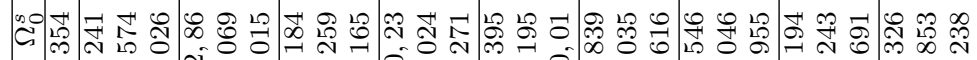

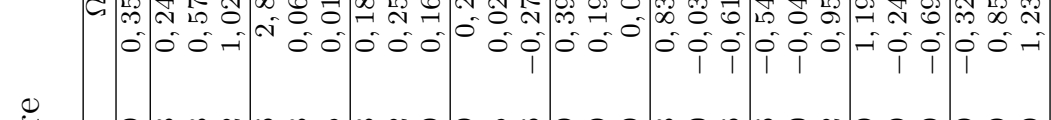
莥

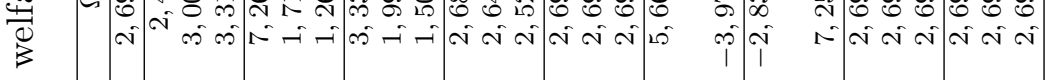

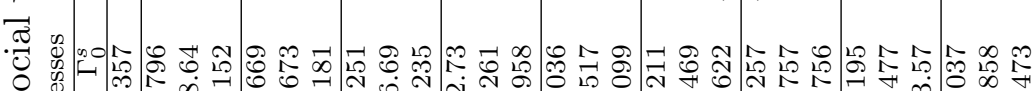
\& Z

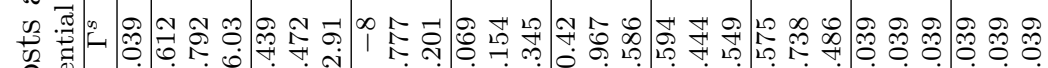

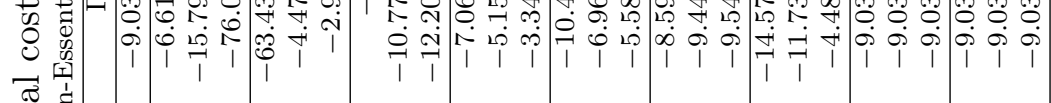

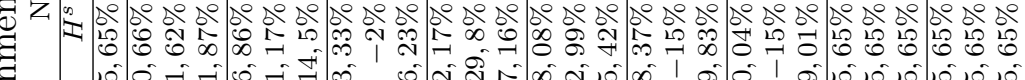

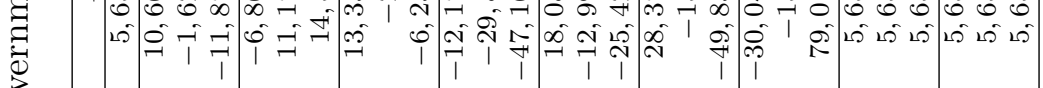

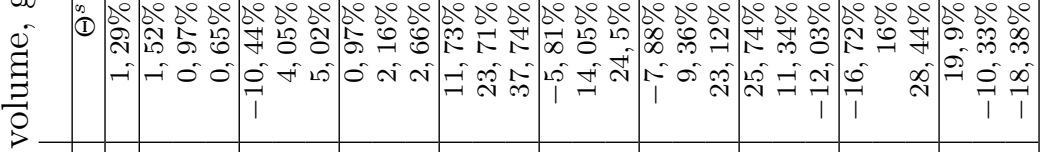

言

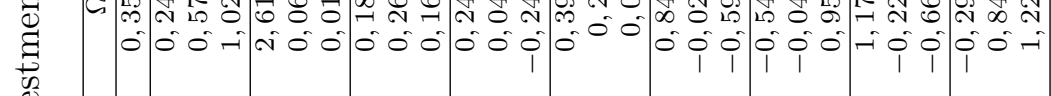
.

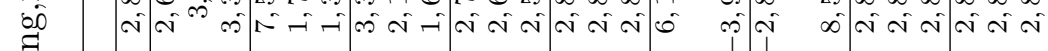
.ב.ב. 

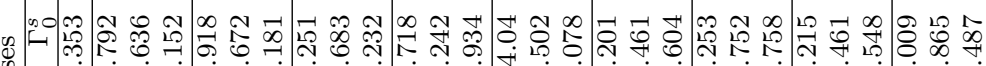

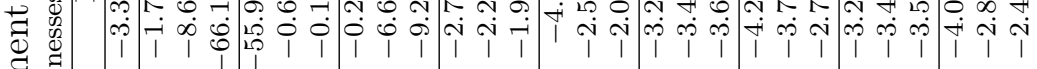

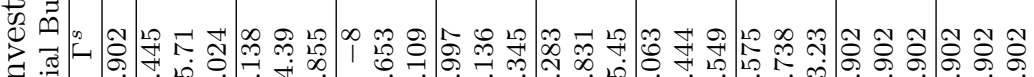

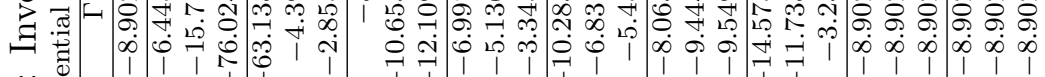

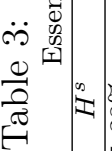

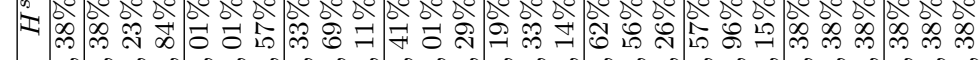
N-

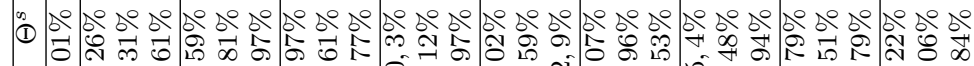

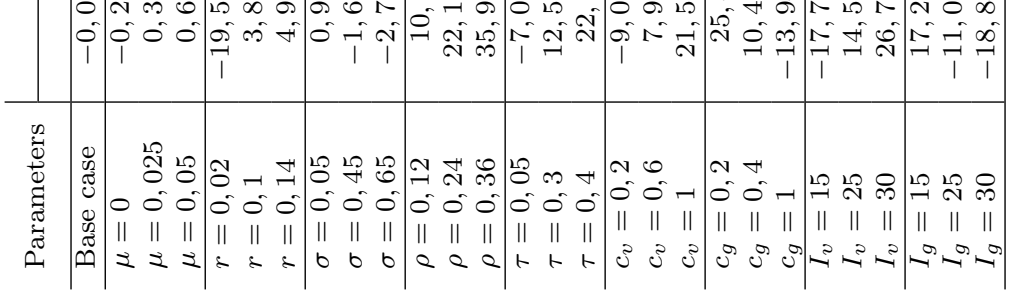

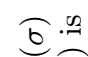

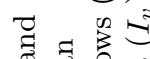

๘ี

क्षे

ज焉虫

氙

象䨌:

象 $\frac{\pi}{0}$

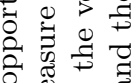
(n)

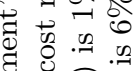

द ङ

क 000

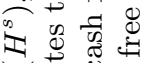
$\cong$ 总 సี घ

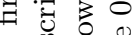
$\exists$ 责 $\infty_{\infty}$ के 9 สี द्वित कि (1) की की

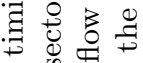
룽 둥

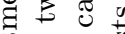
की . $\Xi . \exists$ 获苾

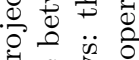
bo

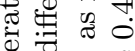
各. สี के むै ज़ ङ 西 $\begin{array}{llll}10 & 2 & 0 \\ 0 & 0 & 0 \\ 0 & 0 & 1\end{array}$ ๑ $\stackrel{5}{0} \stackrel{0}{0}$ రీ 若

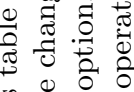

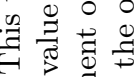

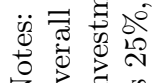




\section{Expropriation Risk}

The model. Both the investor and the government have all the information keys ex-ante. The only uncertainty in this model comes from the cash-flows. Therefore, the level of cash flows that triggers the realization of investment for the private firm, $x_{I}^{e}$, is set knowing all of the following:

- The firm will be expropriated once the cash-flows reach $x_{e}$, the expropriation trigger of the government.

- If expropriation occurs, the government will pay an indemnity $k_{v}$ to the firm and will continue operating the project, facing higher operating $\operatorname{costs} c_{g}$ and a reputational cost, $k_{r}$, that is the consequence of a lower aggregate level of investment. Thus, the government claim turns into that of Proposition 1 minus the costs associated with expropriation risk $\left(k_{v}, k_{r}\right)$.

- $k_{v} \in\left[0, V^{s}(x)\right]$. Two natural boundaries for the compensation are zero (confiscation) and the fair value of the project, $V^{s}(x)$. Compensation offered upon expropriation is either below market value or it does not exist.

- There is an abandonment trigger for the firm, $x_{a}^{e}$, which also depends on the probability of expropriation. As before, abandonment does not imply any cost for the private firm.

- Upon abandonment of the firm, the project will be operated by the government if (i) it belongs to the utilities sector, or (ii) if it's a commodity, and $x_{a}^{e}>x_{a}$.

Note the interaction between the abandonment trigger of the private firm, and the expropriation trigger of the government: upon operations, since there is perfect information, the firm will anticipate whether the government is going to expropriate earlier $\left(x_{e}\right.$ low $)$, and this will lean it towards early abandonment ( $x_{a}^{e}$ high). The triggers mentioned in this case (i.e. $\left.x_{e}, x_{a}^{e}, x_{I}^{e}\right)$ do not have an analytic solution, and they must be obtained by numerically solving a system of non-linear equations (see Appendix).

Proposition 5. Operating value of private provision with expropriation risk. The operating value of a private firm exposed to expropriation risk by the government is

$$
V^{e}(x)=\left(\frac{x}{\theta}(1-\rho)-\frac{c_{v}}{r}\right)(1-\tau)+E_{1} x^{\beta_{1}}+E_{2} x^{\beta_{2}}
$$

where $E_{1}$ and $E_{2}$ are constants given by the conditions on firm value at the moments of abandonment and expropriation. $E_{1}$ is determined by the value of the private firm at expropriation, $V^{e}\left(x_{e}\right)=k_{v}$, while $E_{2}$ arises from the value of the firm at abandonment, $V^{e}\left(x_{a}^{e}\right)=0$. The abandonment trigger, denoted by $x_{a}^{e}$, corresponds to the numerical solution of equation 35, which comes from the smooth pasting condition that requires that $\left.\frac{\partial V^{e}(x)}{\partial x}\right|_{x=x_{a}^{e}}=0$.

$$
\frac{(1-\rho)(1-\tau)}{\delta}+\beta_{1} E_{1} x_{a}^{e \beta_{1}-1}+\beta_{2} E_{2} x_{a}^{e \beta_{2}-1}=0
$$

The value accruing to the government is given by,

$$
G^{i e}(x)=\frac{x}{\theta} \rho+\left(\frac{x}{\theta}(1-\rho)-\frac{c_{v}}{r}\right) \tau+E_{3}^{i} x^{\beta_{1}}+E_{4}^{i} x^{\beta_{2}}
$$

in which the parameters $E_{3}$ and $E_{4}$ are again determined using the value matching conditions for the government. The condition for $E_{3}$ specifies the value of the government at the moment of expropriation: $G^{i e}\left(x_{e}\right)=G^{i}\left(x_{e}\right)-k_{v}-k_{r}$. The condition for $E_{4}$ is that, at the moment of 
abandonment of the private firm, $G^{i e}\left(x_{a}^{e}\right)=G^{i}\left(x_{a}^{e}\right)$. The expropriation trigger, $x_{e}$, is numerically determined by solving the following implicit equation

$$
\frac{(1-\rho) \tau+\rho}{\delta}+\beta_{1} E_{3}^{i} x_{e}^{\beta_{1}-1}+\beta_{2} E_{4}^{i} x_{e}^{\beta_{2}-1}-\left.\frac{\partial G^{i}(x)}{\partial x}\right|_{x=x_{e}}=0
$$

This equation is the result of the smooth pasting condition $\left.\frac{\partial G^{i e}(x)}{\partial x}\right|_{x=x_{e}}=\left.\frac{\partial G^{i}(x)}{\partial x}\right|_{x=x_{e}}$, which simply states that not only the value but also the derivative of the government's functions match at the moment of expropriation.

The constants on the value equations of the firm can be interpreted as follows. $E_{1}$ captures the private firm's expected loss from the option to expropriate that the government holds. Thus, it should be below zero because expropriation has a negative impact on the firm. Moreover, since $\beta_{1}>1$, as the cash flows, $x$, increase, the expropriation option will have a larger impact on the value of the project (the term $E_{1} x^{\beta_{1}}$ in eq. 34 ). On the other hand, $E_{2}$ captures the value of the abandonment option to the firm. As such, $E_{2}$ will be positive. Since $\beta_{2}<0$, as the cash flows increase, the value of the abandonment option will be close to zero, and vice versa.

The constants in the government's equations have an analogous interpretation. $E_{3}$ makes reference to the expected profit of the government from expropriating the project. Therefore, $E_{3}^{i}$ will be positive for either sector. Besides, the term $E_{3}^{i} x^{\beta_{1}}$ will be increasing on cash flows (because $\beta_{1}>1$ ), so the higher the level of cash flows, the larger the impact of the option to expropriate in government's value. In turn, the constant $E_{4}^{i}$ can be interpreted as the valuation that the government makes of the firm's abandonment option. Since the government has a specific condition upon the private's abandonment for each sector, the values for essential and non-essential activities will be different. If the project is essential the constant will be negative, $E_{4}^{u}<0$, because the government is forced to operate the project afterwards, but if the project is non-essential, then the constant will be positive, $E_{4}^{c}>0$, because of the abandonment option embedded in the government's value. Again, since $\beta_{2}<0$, the term $E_{4}^{i} x^{\beta_{2}} \forall i=u, c$ will be decreasing as cash flows increase, so that the value of the abandonment option will be less important for high revenue states.

Proposition 6. Project value of private provision with expropriation risk The claim for the private firm on the investment opportunity is given by:

$$
V_{0}^{e}(x)= \begin{cases}{\left[\frac{x}{\delta}(1-\rho)-\frac{c_{v}}{r}\right][1-\tau]+E_{1} x^{\beta_{1}}+E_{2} x^{\beta_{2}}-I_{v}} & \text { if } x \geq x_{I}^{e} \\ {\left[\left[\frac{x_{I}^{e}}{\delta}(1-\rho)-\frac{c_{v}}{r}\right][1-\tau]+E_{1} x_{I}^{e \beta_{1}}+E_{2} x_{I}^{e \beta_{2}}-I_{v}\right]\left[\frac{x}{x_{I}^{e}}\right]^{\beta_{1}}} & \text { if } x<x_{I}^{e}\end{cases}
$$

And the investment trigger, $x_{I}^{e}$ comes from the implicit equation:

$$
\left(\beta_{1}-1\right) \frac{(1-\rho)(1-\tau)}{\delta} x_{I}^{e}-\beta_{1}\left(\frac{c_{v} \tau}{r}+I\right)+\left(\beta_{1}-\beta_{2}\right) E_{2} x_{I}^{e \beta_{2}}=0
$$

The claim for the government when the government is threatening with expropriate:

$$
G_{0}^{i e}(x)= \begin{cases}\frac{x}{\theta} \rho+\left(\frac{x}{\theta}(1-\rho)-\frac{c_{v}}{r}\right) \tau+E_{3}^{i} x^{\beta_{1}}+E_{4}^{i} x^{\beta_{2}} & \text { if } x_{I}^{e} \leq x \\ {\left[\frac{x_{I}^{e}}{\delta} \rho+\left(\frac{x_{I}^{e}}{\delta}(1-\rho)-\frac{c_{v}}{r}\right) \tau+E_{3}^{i} x_{I}^{e \beta_{1}}+E_{4}^{i} x_{I}^{e \beta_{2}}\right]\left[\frac{x}{x_{I}^{e}}\right]^{\beta_{1}}} & \text { if } x<x_{I}^{e}\end{cases}
$$


In the model, we include three types of costs of expropriation. The first one is related with the relative inefficiency of the government when compared with the private firm, and is implicit in the model. This comes from two flanks. On the one hand, retaliation can increase the operating costs of the firm (e.g. Raff (1992)). For instance, financial markets can be closed for the country so that it does not have enough funding, or if it does, it comes probably at a higher cost (Tomz and Wright, 2010). But it can also present itself as a direct increase in price of inputs. The case of Argentina provides a good example: after the expropriation of Repsol YPF, the Government faced about $26 \%$ additional cost for buying Liquefied Natural Gas from firms other than Repsol, which refused to sell the product as it usually did. On the other hand, there is a direct loss from the project being run by a government, usually less efficient than private firms (Raff, 1992; Stroebel and van Benthem, 2010; Schwartz and Trolle, 2010; Guriev et al., 2011).

The second one is a reputation cost for the government, which we denote by $k_{r}$. It is usually considered as a reduction in investment that occurs when the government expropriates firms. Empirical evidence of this can be seen in Gastanaga et al. (1998), who find a negative relationship between inflows of FDI and nationalization risk in 49 Least Developed Countries (LDCs), and Allee and Peinhardt (2011), who -although not focused purely in expropriation, show that not only present but also past disputes in the International Centre for Settlement of Investment Disputes -ICSID, reduce the level of FDI that enters non-OECD countries. This means that reneging on contracts and expropriating, among other actions, do create a 'stigma' for these countries. At the theoretical level, this cost is accounted for in Schwartz and Trolle (2010) as an exogenous quantity that reduces the value for the government, while in Clark (2003) it is modeled as a Geometric Brownian Motion correlated with the value of the expropriated subsidiary, in order to account for the wide range of variables that affect the cost of expropriation.

Finally, $k_{v}$, includes any costs associated with indemnities paid by the government at the moment of expropriation. In the fashion of Guriev et al. (2011), Engel and Fischer (2010) and Schwartz and Trolle (2010), we account for this type of cost. It is, together with taxes and royalties, one of the control variables of the government in this case. While taxes and royalties have a direct impact on the government's cash-flows, and thus on the level of political risk, $k_{v}$, is the key variable in making decisions on political risk. It is inversely related with the probability of expropriation: the bigger the indemnity paid to the private firm, the lower the probability of expropriation ( $x_{e}$ will be high). That is: if $k_{v} \rightarrow \infty$, then $x_{e} \rightarrow \infty$, and $E_{1} \rightarrow 0$, which means that for high levels of $k_{v}$, the results under expropriation will converge to the safe case of Proposition 3 (e.g. $x_{I}^{e} \rightarrow x_{I}^{s}, x_{a}^{e} \rightarrow x_{a}^{s}, V^{e}(x) \rightarrow V^{s}(x)$ ). If, instead, $k_{v} \rightarrow 0 \Rightarrow x_{e} \rightarrow 0$, the private firm would never enter, since this implies immediate expropriation.

\subsection{The exogenous case}

At this point we consider all three costs to be exogenous. While the inefficiency cost can be easily defined as exogenous since it depends on variables that are beyond control for the government, for instance, due to employees' weak incentives (see Shleifer (1998)), the reputation cost and the indemnity cost can be closely related: a government that pays a fair compensation to the firm after expropriation may have to bear a smaller reduction in investment afterwards. Yet, there is at least some exogenous component in them. On the one hand, there may be legal costs inherent to arbitration procedures associated with the indemnity payment. And on the other hand, political leaders in democracies may face audience costs, which are generated through the domestic political process: "[e]ven if expropriations are politically popular, voters have the incentive to replace political leaders with tarnished reputations" (Jensen, 2008, 1042). Autocrats expecting to rule for a long time, may also face a similar reputation cost by not protecting the property of their subjects (see Clague et al. (1996)).

In order to analyze the effects of expropriation risk in the investment decisions of a firm, we set the base case parameters so that the government offers a fixed compensation in case 
of expropriation, equal to half the fair value of the project at the initial cash flow level, $k_{v}=$ $\left.0.5 * V^{s}(x)\right)$, and we assume the fixed reputation costs to be $k_{r}=5$. Our results show that the firm's investment will be suboptimal when the government creates a threat of expropriation. By sub-optimality we mean that the firm will invest earlier than in the safe case ${ }^{9}\left(x_{I}^{e}<x_{I}^{s}\right)$, but it will also abandon earlier the project $\left(x_{a}^{e}>x_{a}^{S}\right)$. At first sight, this may seem a bit counterintuitive. However, consider that waiting longer to invest means that there is a bigger probability that the cash-flows will get closer to the risk trigger $x_{e}$, which increases the probability of being expropriated sooner. Thus, the smaller scope to bear losses comes from a higher abandonment trigger. An important consequence of this last result is that, since the government is obliged to undertake the essential projects upon firm's abandonment, it will be more costly to create threats of expropriation in this case than in the case of commodities.

Table 4 summarizes the results obtained for the case of expropriation and the dynamics of the results. One of the most interesting things of this model is that it allows for analyzing the interactions among $x_{I}^{e}, x_{a}^{e}$ and $x_{e}$. Results show that increases in the growth rate accelerate the investment decision of the private and decelerate abandonment (lower $x_{a}^{e}$ and $x_{I}^{e}$ ), in spite of the decrease in the expropriation trigger. The exact opposite effect is observed when the interest rate increases: as explained earlier, the bigger discounting in costs comes along with an even larger discount of benefits, therefore delaying the decision to invest and rushing the decision to abandon. This also explains why expropriation trigger increases as interest rate increases. Since the option to expropriate can be considered as an American call option (Clark, 2003; Schwartz and Trolle, 2010), a higher volatility of cash flows delays both decisions of the private firm (higher $x_{a}^{e}$ and $x_{I}^{e}$ ), as well as the decision to expropriate (higher $x_{e}$ ).

As for fiscal variables, there is an interesting feature related with the expropriation trigger: higher government take through both royalties $(\rho)$ and taxes $(\tau)$ reduces the incentives of the government to expropriate. Raff (1992), Rigobon (2010), Stroebel and van Benthem (2010), and Schwartz and Trolle (2010) arrive to a similar conclusion. The decision to abandon, however, depends on the fiscal variable: while higher royalties increase the abandonment trigger, a higher tax rate delays the decision to abandon. This difference comes from the less distortive nature of taxes: in normal conditions, they don't affect the abandonment decision, which means that the decrease in $x_{a}^{e}$ is solely the result of a lower probability of being expropriated $\left(\downarrow x_{e}\right)$. Efficiency of the private firm has a similar impact to that of royalties: the higher the operating costs are, the faster abandonment and expropriation occur. We interpret this result as evidence that mechanisms such as transfer pricing -a form of tax avoidance, may be in detriment of private firms' "safety", since the fact that they are perceived as trying to take too much without compensating the government for their operations in the country gives all the more reasons to expropriate. As Rigobon (2010) points out, there's often an incentive to seize rents from private corporations whenever the revenues they obtain are perceived as excessive.

The values of the private firm $\left(V^{e}, V_{0}^{e}\right)$ and the government $\left(G^{e}, G_{0}^{e}\right)$ increase with a higher rate of return, with a lower interest rate and with a higher efficiency of the private (lower $c_{v}$ and $I_{v}$ ), just like in the case without political risk. However, with the threat of expropriation, the dynamics related with volatility of cash flows is somewhat different. The government value for non-essential activities shows the same dynamics as before, but private firm's value is affected negatively, and the government value for essential activities now increases as volatility increases. This is due to the option to expropriate, which increases in value as cash flows get more volatile, like in Clark (2003) and Schwartz and Trolle (2010).

As for the differences between essential and non-essential economic activities, the government faces different constraints and this yields different incentives in each case. For essential activities, the government has a higher expropriation trigger than for non-essential activities. This means that expropriation is less likely to occur in a project that is considered essential for the functioning

\footnotetext{
${ }^{9}$ Nordal (2001) obtains a similar result in that higher risk accelerates the investment decisions of the firm.
} 
of the economy, because of the extra cost imposed by the lack of an abandonment option of the government. Note, however, that for the private firm there are no significant differences regarding decisions of when to invest and when to abandon, and thus, the value ex-ante and ex-post is not particularly affected either. This can be explained by the fact that, although the probability of expropriation is higher in the case of non-essential activities, the difference is not large enough for the firm to require additional compensation upon expropriation.

\subsubsection{Investment, public and welfare effects of expropriation risk}

The analysis regarding timing, volume of investment, as well as social welfare is done based on the measurements proposed in section 3.2. Therefore, we have:

Expected time to investment: shows the changes in the investment timing induced by expropriation risk

$$
\Theta^{e}=\frac{\theta^{e}-\theta^{s}}{\theta^{s}}=\frac{\ln \left(x_{I}^{s}\right)-\ln \left(x_{I}^{e}\right)}{\ln \left(x_{0}\right)-\ln \left(x_{I}^{s}\right)} .
$$

If $\Theta^{e}<0$ it means the private firm accelerates the realization of investments in the presence of expropriation, and if $\Theta^{e}>0$ it means investments are delayed relative to the case of no risk.

Change in firm's value: shows, in relative terms, the amount in which private investment is reduced, once expropriation is on the table.

$$
H^{e}=V^{e}\left(x_{0}\right) / V^{s}\left(x_{0}\right)-1 .
$$

Cost for the government: The cost of the government, $\Gamma^{e}$, shows the difference in value between the case of expropriation and the safe case. Thus, it can also be interpreted as the value of the option to expropriate. For an operating business and it expressed as:

$$
\Gamma^{e}=G^{e}\left(x_{0}\right)-G^{s}\left(x_{0}\right),
$$

The cost for an individual investment opportunity is:

$$
\Gamma_{0}^{e}=G_{0}^{e}\left(x_{0}\right)-G_{0}^{s}\left(x_{0}\right) .
$$

Social Welfare: In the same fashion, we define change in social welfare as the change in total value creation in the economy.

$$
\Omega^{e}=\left(V^{e}(x)+G^{E}(x)\right)-\left(V^{s}(x)+G^{s}(x)\right)
$$

and the social welfare for an investment opportunity is given by,

$$
\Omega_{0}^{e}=\left(V_{0}^{e}(x)+G_{0}^{e}(x)\right)-\left(V_{0}^{s}(x)+G_{0}^{s}(x)\right)
$$

Table 5 contains the effects of expropriation. First, investment is always reduced when compared with the safe case, as shown by the negative sign in $H^{e}$. This reduction is more apparent when the change in parameter is associated with a lower expropriation trigger: a higher growth rate and a lower interest rate, reduced costs of expropriation (low $k_{r}$ and $k_{v}$ ), and a lower government take (low $\rho$ and $\tau$ ). All these variables make expropriation more valuable for the government ( $\Gamma^{e}$ and $\Gamma_{0}^{e}$ increase).

Second, expropriation risk reduces total value creation (negative values for $\Omega^{e}$ and $\Omega_{0}^{e}$ ), except when the private firm is very inefficient at the operational level relative to the government. Investment efficiency doesn't have the same impact. In addition to this, when both agents have 
the same operating costs, the welfare loss in the economy is zero. This means that the reduction in the investment volume of the private firm, is fully counterbalanced by the increase in value of the government (through the value of the expropriation option).

Third, investment timing is negative in most of the cases, implying that in general terms, under the threat of expropriation, the firm will accelerate investment as predicted earlier. As expropriation becomes less likely (high $x_{e}$ with respect to $x_{I}^{e}$ ), our investment timing measure $\Theta^{e}$ goes to zero. The only exception to the rule comes from the case of an increase in volatility: a higher risk in cash flows delays the decision to expropriate in a more dramatic way than the decision to invest of the private firm. However, more volatile cash flows increase the probability that the expropriation option will be exercised, thus generating a an even higher acceleration of the decision to invest in the case of political risk.

Finally, when comparing the two economic activities, we can see again that the private firm has nearly the same results for both of them. However, in the very few occasions when there are differences in the investment volume, we can see that the greater reduction in investment happens in non-essential businesses. Associated with this is the fact that the government's expropriation option is more valuable in non-essential business, where it holds the abandonment option. In line with these results, the welfare losses generated by the threat of expropriation are also higher in the essential activities projects. 


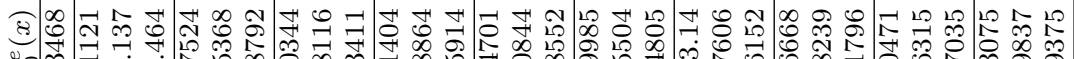

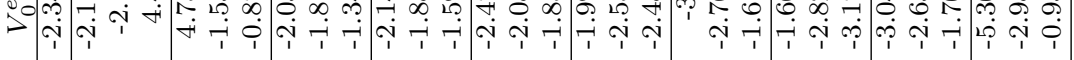

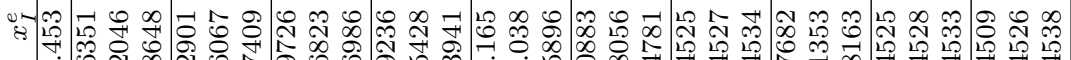
م.

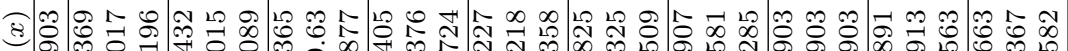

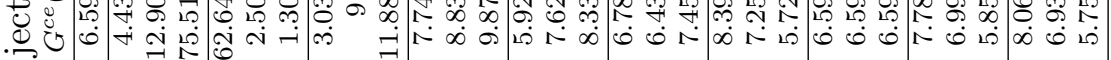

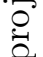

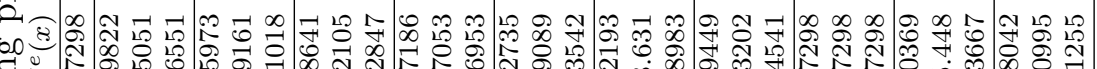

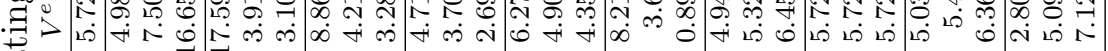
苛

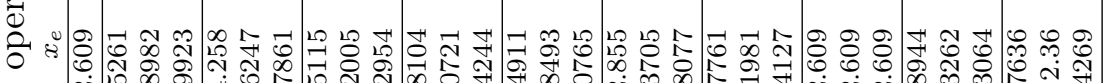

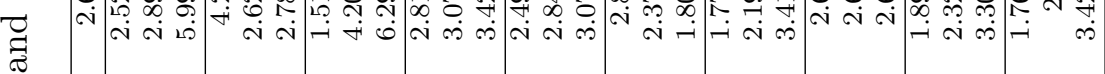

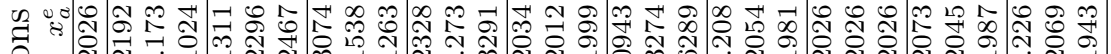
营

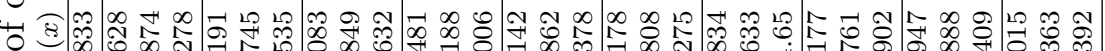

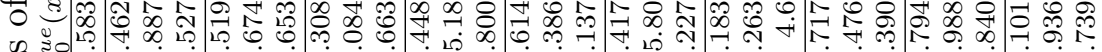
Q 刍

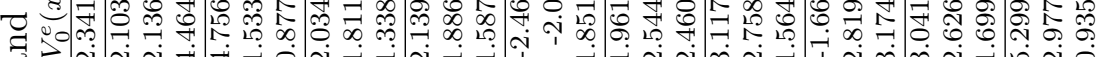
ส 党: $\Xi \quad \omega$ ल

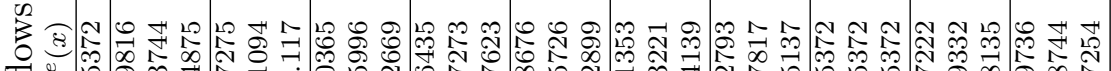

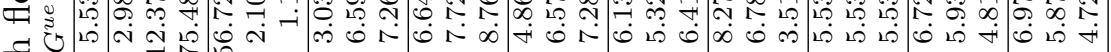
表

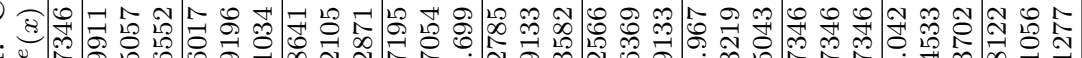

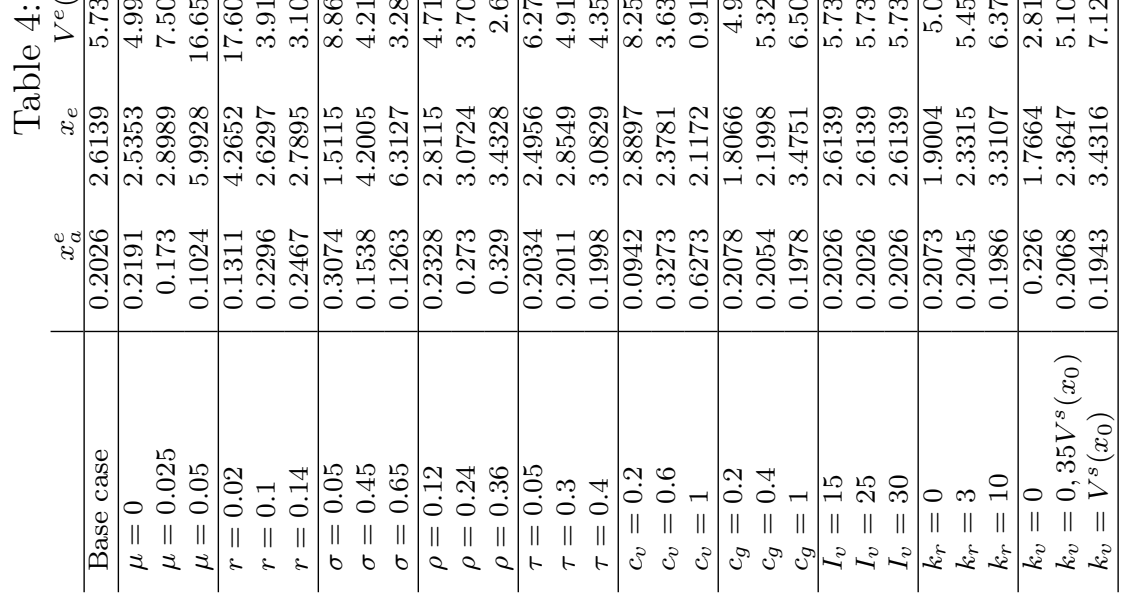




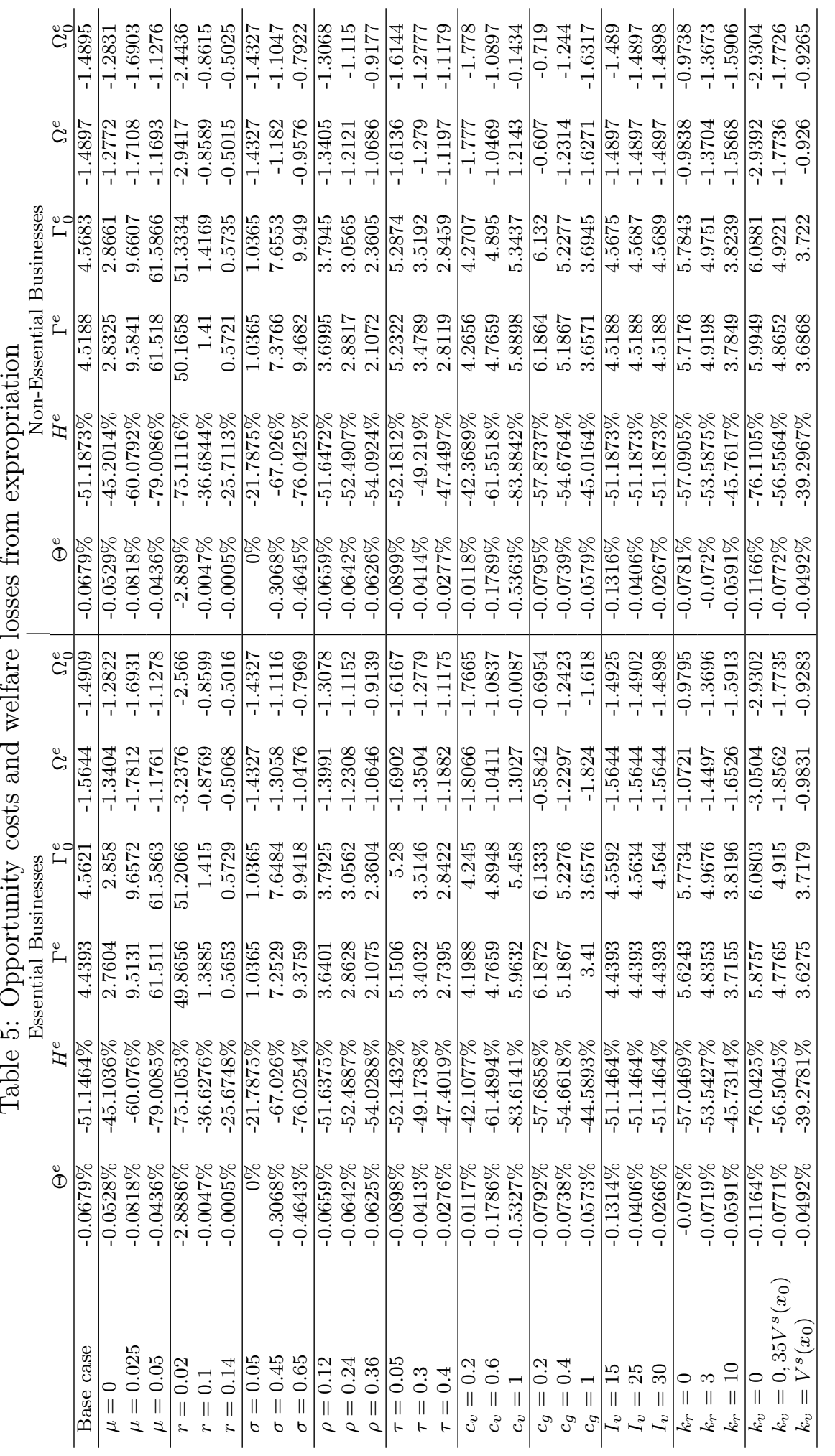

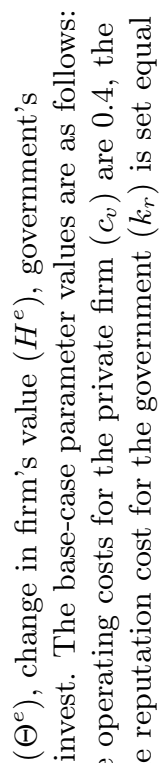
so 욜

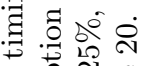

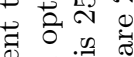
ฮี ซี

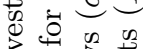
. 荝泀焉 ㄴ 40 青定当

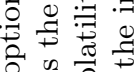
o 용 击

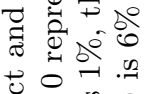
造. 荤 产 苋的宫

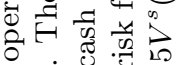

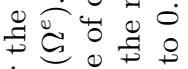
눙

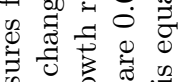
品

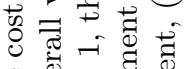

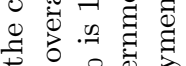
की

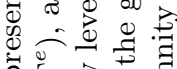

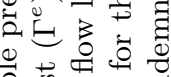

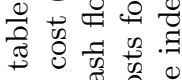

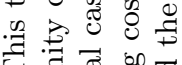

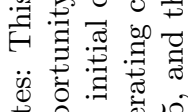

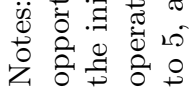




\subsection{The endogenous case for indemnity and reputational costs}

In the previous case we assumed that all the decisions in terms of indemnity and reputation costs were exogenous, in the fashion of Schwartz and Trolle (2010), Guriev et al. (2011), and Clark (2003). Now we turn away from them by analyzing what would the decision of the government be in terms of indemnity. This way we make the compensation the government would pay in case of expropriation contingent on reputation costs (in terms of investment). Since the probability of expropriation is closely related with the indemnity, this function allows the government to find whether it is optimal to make expropriation more likely, in the sense that expropriation may occur very soon.

Remember that this government is not a benevolent one. It is only interested in its profits. Therefore, the decision on the indemnity is completely based on what the government might gain or lose with the threat to expropriate one firm. However, the real impact in the economy is different than that of the governmental gain, so we also measure the total gain/loss in the overall economy as a result of the threat to expropriate one firm. In order to construct these measures, we assume that:

- There are $m+1$ firms operating in the economy, and $l$ firms willing to enter.

- The government has a target firm that it wants to expropriate. Therefore, the expropriation threat is directed only to such firm.

- The firms remaining in the market -either operating or entrants, however, do not know that they are not a target. Therefore, in terms of value, this means that they act as if they were subject to expropriation, but the government accounts for them as if they are safe.

In terms of decision making then, when determining $k_{v}$, the government maximizes its gain from expropriation. This means that it calculates a global value function $G_{g}$, in which it accounts for the net gain from expropriation, as well as the possible gain/loss from creating the threat to operating and entrant firms. Such function varies in $k_{v}$ so that the government can determine the optimal value of the indemnity.

$$
G_{g}=G^{e}(x)-G^{s}(x)+m\left(G^{s}\left(x_{a}^{e}, x\right)-G^{s}(x)\right)+l\left(G_{0}^{s}\left(x_{a}^{e}, x_{I}^{e}, x\right)-G_{0}^{s}(x)\right)
$$

In terms of welfare, the effects of expropriation are

$$
\begin{array}{r}
W_{g}=\left(G^{e}(x)+V^{e}(x)-\left(G^{s}(x)+V^{s}(x)\right)\right) \\
+m\left(G^{s}\left(x_{a}^{e}, x\right)+V^{s}\left(x_{a}^{e}, x\right)-\left(G^{s}(x)+V^{s}(x)\right)\right) \\
+l\left(G_{0}^{s}\left(x_{a}^{e}, x_{I}^{e}, x\right)+V_{0}^{s}\left(x_{a}^{e}, x_{I}^{e}, x\right)-\left(G_{0}^{s}(x)+V_{0}^{s}(x)\right)\right)
\end{array}
$$

The idea here is that upon expropriation of one firm, the remaining firms react to such expropriation by reducing their scope to bear losses. In certain way, this can be explained by a smaller amount of investment on the firm. Thus, it can be related to the result of Cole and English (1991): in their setting, atomistic investors must decide every period on the additional investment they will put in the host country; given certain conditions, one possible equilibrium yields an intermediate level of investment and a moderate probability of expropriation, so that investment is not completely swept off. As for entrants, the reputational consequences for the government come at the cost of the firm investing and abandoning at an earlier stage. Thus, the value of the investment option for the government is smaller whenever it creates a threat of expropriation.

Figure 1 shows the maximum possible gain, as described in equation 47 for the government in both sectors (panels (a), and (c)), and the compensation offered to the firm, as a proportion of the fair value, associated with it (panels (b), and (d)). Notice that the gain the government 
Figure 1: Maximum gain and optimal compensation

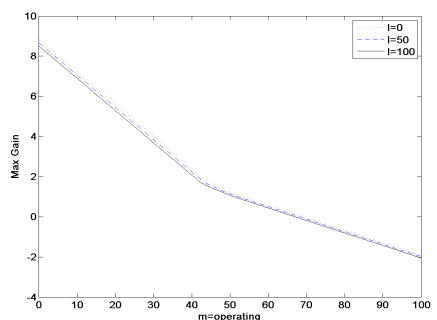

(a) Gain - Essential

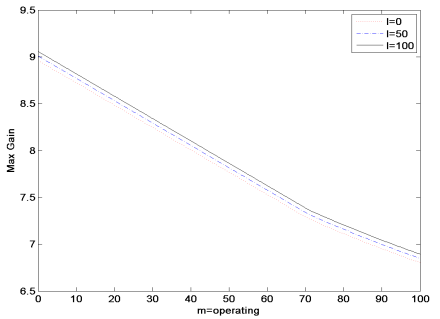

(c) Gain - Non Essential

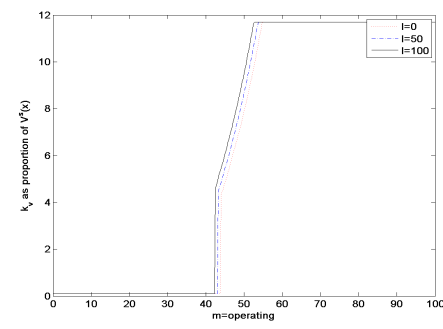

(b) Optimal $K_{v}$ - Essential

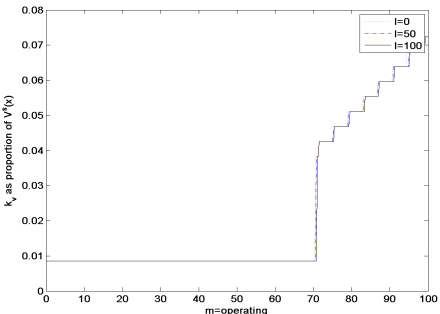

(d) Optimal $K_{v}$ - Non Essential

obtains from expropriating one firm is decreasing in the number of firms operating. In the case of essential activities, when the market is big ( $m$ is large), the optimal policy is to offer the highest possible compensation to the firm $\left(V^{s}(x)\right)$. This is explained by the fact that firms operating account for the risk by increasing their abandonment trigger, so that the probability that the project is abandoned increases too. This is costly for the government because it is less efficient than the private firm, and has no option but to take the project once it has been abandoned. Thus, the larger $m$, the smaller the governmental gain.

In contrast, for non essential activities, the government's optimal policy to maximize its gain is to confiscate the firm when the market is small, and to offer a low compensation (below $10 \%$ of the fair value) when the market is big. The difference between both sectors comes from the abandonment option that the government holds in the case of non essential activities. Since the government does not have to keep the facility running if the private firms abandon the project, all it loses is taxing income. Moreover, given the fact that they abandon at the politically risky level, the government can continue operating the facility afterwards, since $x_{a}<x_{a}^{e}$ at the confiscation policy $\left(k_{v}=0\right)$. Also, notice that the gain is increasing in the number of firms willing to enter, because the earlier they enter, the faster the government starts obtaining income from taxes.

Figure 2: Maximum welfare

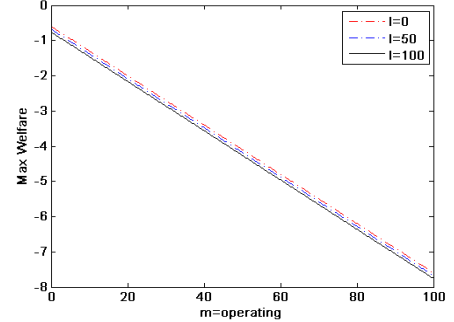

(a) Essential

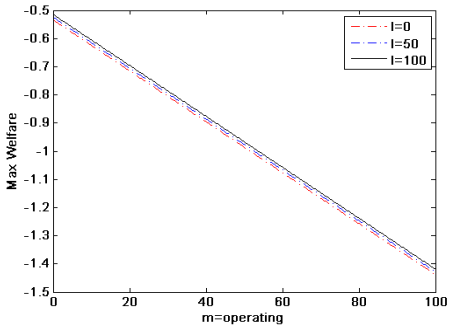

(b) Non Essential

Figure 2 presents the maximum welfare gain that the government can achieve in the presence 
of expropriation risk, that is, the maximum value of the function $W_{g}$ (equation 48). Notice that whether the activity is essential for the economy (panel (a)) or not (panel (b)) there is always a loss that increases with market size. Thus, the government should always offer the highest possible compensation to the target firm in order to minimize the overall value loss. This is consistent with the results obtained in the benchmark case without expropriation risk, and in the exogenous case: the fact that the government does not have the option to abandon essential businesses makes it more valuable to have a more efficient agent operating the project. Therefore, it is also more costly to create the threat for the economy in general.

Figure 3: Low vs. High Taxes for Non-Essential Activities

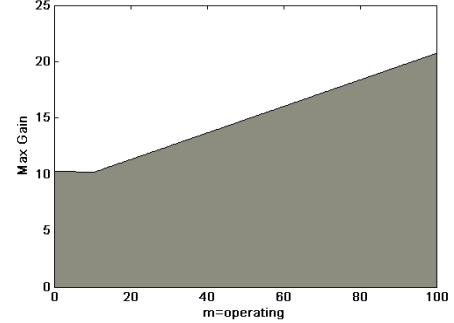

(a) Gain, $\tau=5 \%$

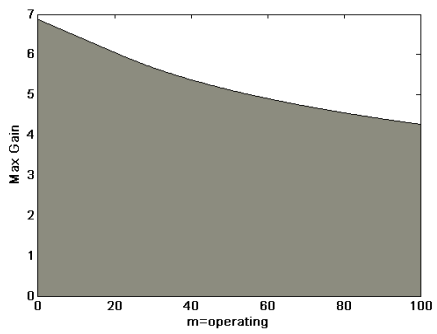

(c) Gain, $\tau=30 \%$

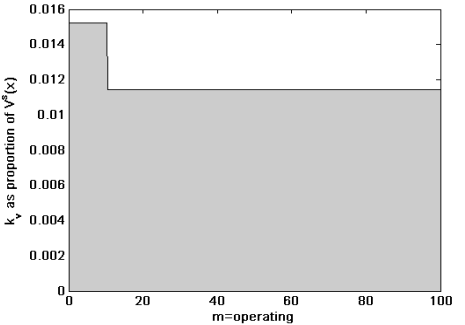

(b) Optimal $k_{v}, \tau=5 \%$

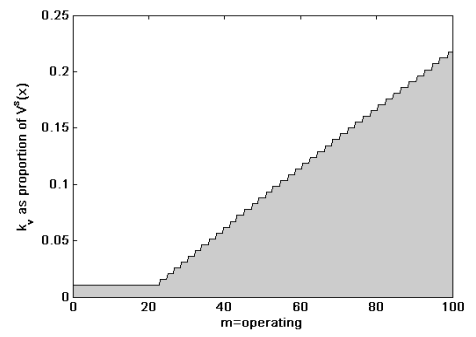

(d) Optimal $k_{v}, \tau=30 \%$

The other key variables that the government can control are taxes and royalties, which, by increasing government take, have a direct impact on the expropriation trigger, and therefore in the level of political risk ${ }^{10}$. Taxes and royalties have different impacts on the optimal policy of the government, since royalties seem to distort in a more visible way the decisions of the private firm. In the case of taxes, if the activity is not essential (figure 3), low taxes induce the government to confiscate the firm disregarding the size of the market, and high taxes to pay a compensation below $25 \%$ of the fair value of the fair value of the firm, in order to maximize its gain. Although the gain decreases from one case to the other, there is always a gain from expropriating the target firm.

If the activity is essential for the economy (figure 4), then low taxes make the government confiscate the firm for small to medium sized markets, and pay a high compensation only when the market is big enough: instead of maximizing a gain, the government has to minimize the loss of expropriation. A higher tax rate, in turn, makes the government offer $100 \%$ of the fair value of the firm as compensation even for smaller markets in order to maximize its gain from expropriation, which becomes negative for medium to large markets.

Higher taxes in the presence of political risk delay both the option to invest, and the option to abandon ${ }^{11}$, which explains why the effect of taxes is so tangible in terms of gains and losses: The interval in which the government receives fiscal revenue is larger, and the incentive to expropriate

\footnotetext{
${ }^{10}$ We omit $l$ from this analysis, since it has a negligible effect, as can be seen from previous figures.

${ }^{11}$ The latter is merely an interaction between the expropriation trigger and the abandonment trigger, since abandonment in normal conditions is neutral to taxes.
} 
Figure 4: Low vs. High Taxes for Essential Activities

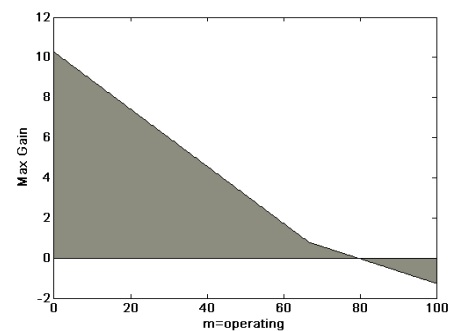

(a) Gain, $\tau=5 \%$

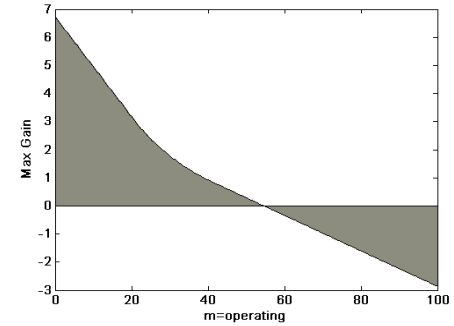

(c) Gain, $\tau=30 \%$

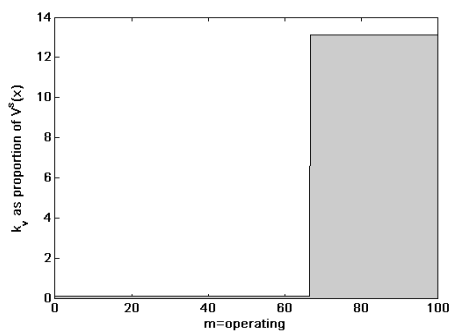

(b) Optimal $k_{v}, \tau=5 \%$

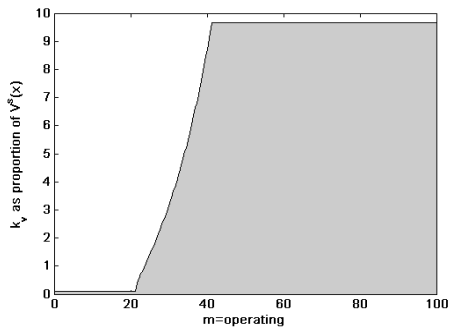

(d) Optimal $k_{v}, \tau=30 \%$

is smaller. Therefore, when taxes are high, there is more to lose with the threat to expropriate in either sector: in order to maximize its gain, the government must offer a high compensation to the firm even if the market is still small.

Royalties have a more dramatic impact on the optimal policy of the government regarding the indemnity payment that it offers to the target firm. A moderate to high royalties rate is the only case in which the government is induced to offer the highest possible compensation to the firm in order to maximize the gain from expropriation when the business is not essential. This is because the distortion that it creates in terms of incentives of the private firm is more noticeable, in line with the idea that they lead the firm to stop operations before it is optimal to do so (Bergstrom, 1984). This is also more visible in terms of welfare: paying the highest possible compensation to the firm increases dramatically the loss that the overall economy experiences.

\section{Concluding remarks}

This paper uses a real options model to analyze the irreversible decisions that must be made by a firm and by a government regarding investment in a new project. The firm must decide when to undertake the project, and when to shut it down, knowing that the government may not credibly commit to not expropriate once investment costs have been sunk. We consider that the project may be operating in one of two sectors in the economy, one of which is essential for the government. This means that the government will have to keep essential businesses on operations if the cash flows trigger abandonment of the project by the private firm. If the project is not essential, the government takes it after abandonment only if it is profitable.

This paper answers questions regarding three main issues. First, we analyze what drives the government to expropriate. We find that the decision to expropriate is delayed when the relative efficiency of the private firm and the government's fiscal income (high royalties and taxes) increase, because the value of the option to expropriate is worth less. In turn, when the cash flow growth rate and volatility are high, the government is more prone to expropriate. Although increases in volatility imply a larger value for the government, we observe that if the project is in the essential sector the value of the option to expropriate is lower and increases less than in 
the case of a non-essential project, due to the existence of an option to abandon in the latter.

Second is the question of how firms react to expropriation. In general, operating in a politically risky environment accelerates both investment and abandonment. Cases in which expropriation takes longer to occur are related with the firm waiting longer to invest and to abandon because of the reduced risk. However, the interaction between the expropriation decision and the abandonment decision is important to answer this question; there are two cases worth noticing. On the one hand, when cash flow growth is high, even though there is a larger risk of expropriation (lower $x_{e}$ ), the firm waits longer to abandon, because the larger cash flows compensate for the expropriation risk bearing. On the other hand, the fiscal variables have a different impact on the abandonment decision. Taxes generate a reduction in the abandonment trigger: a higher tax rate, lowers the risk of expropriation (increases $x_{e}$ ) and as a consequence, the firm waits longer to abandon. We know that the reduction in $x_{a}^{e}$ is the direct consequence of the firm being exposed to less risk, because the abandonment decision in a safe environment is neutral to taxes. Royalties, in turn, distort the abandonment decision of the firm, so that the firm abandons earlier with higher royalties in spite of the smaller expropriation risk that it has to bear. The implication of this is that in the presence of expropriation risk, the firm will be better off paying more taxes, as long as they do not have a direct impact on the abandonment decision.

Finally, we analyze the costs of expropriation. Instead of assuming only exogenous reputation and indemnity costs, our construction allows to study the interaction between both of them. We can calculate the costs or benefits faced by an opportunistic government when it threatens one firm with expropriation, and determine the loss in terms of welfare that this expropriation threat can cause. The results of our model show that when the business is essential for the functioning of the economy, there is a greater welfare gain with a private, more efficient firm operating the project, than in the case where the business is not essential. Therefore, creating a threat to expropriate is also more costly in terms of welfare for essential businesses.

The previous results go in line with results we obtain by endogenizing the reputation costs of expropriation: for essential activities, the government's optimal policy to maximize its gain is generally to expropriate the firm instead of confiscating; it is bound to offer a rather fair compensation, especially if the market is big. However, when the business is not essential, the government generally maximizes its gain by confiscating the firm or paying a low compensation whatever the size of the market. In terms of welfare, however, whether the business is essential to the economy or not, the government should always pay the highest possible compensation to the firm. Since the offered indemnity has a negative relationship with the probability to expropriate, this implies that expropriation will always be suboptimal when it comes to total value creation in the economy.

\section{References}

Allee, T. and C. Peinhardt (2011). Contingent credibility: The impact of investment treaty violations on foreign direct investment. International Organization 65, 401-432.

Bergstrom, T. (1984). Property Rights and Taxation in the Australian Minerals Sector. In L. Cook and M. Porter (Eds.), The Minerals Sector and the Australian Economy, pp. 175-189. Sidney: George Allen \& Unwin.

Clague, C., P. Keefer, S. Knack, and M. Olson (1996). Property and contract rights in autocracies and democracies. Journal of Economic Growth 1(2), 243-276.

Clark, E. (1997, June). Valuing political risk. Journal of International Money and Finance 16(3), $477-490$. 
Clark, E. (2003, May). Pricing the Cost of Expropriation Risk. Review of International Economics 11(2), 412-422.

Cole, H. L. and W. B. English (1991). Expropriation and direct investment. Journal of International Economics 30(3), 201-227.

Eaton, J. and M. Gersovitz (1984). A theory of expropriation and deviations from perfect capital mobility.

Engel, E. and R. Fischer (2010). Optimal resource extraction contracts under threat of expropriation. In W. Hogan and F. Sturzenegger (Eds.), The Natural Resources Trap: Private Investment Without Public Commitment, NBER Working papers, pp. 161-196. MIT Press.

Eom, Y. H., J. Helwege, and J.-z. Huang (2004). Structural models of corporate bond pricing: An empirical analysis. Review of Financial studies 17(2), 499-544.

Gastanaga, V., J. Nugent, and B. Pashamova (1998). Host country reforms and FDI inflows: how much difference do they make? World Development 26(7), 1299-1314.

Gorbenko, A. S. and I. A. Strebulaev (2010). Temporary versus permanent shocks: Explaining corporate financial policies. Review of Financial Studies 23(7), 2591-2647.

Guriev, S., A. Kolotilin, and K. Sonin (2011). Determinants of nationalization in the oil sector: A theory and evidence from panel data. Journal of Law, Economics, and Organization 27(2), 301-323.

Jensen, N. (2008, September). Political Risk, Democratic Institutions, and Foreign Direct Investment. The Journal of Politics 70 (04), 1040.

Jensen, N. M. and N. P. Johnston (2011, May). Political Risk, Reputation, and the Resource Curse. Comparative Political Studies 44(6), 662-688.

Le, Q. V. and P. J. Zak (2006). Political risk and capital flight. Journal of International Money and Finance 25(2), 308-329.

Lensink, R., N. Hermes, and V. Murinde (2000). Capital flight and political risk. Journal of international Money and Finance 19(1), 73-92.

McDonald, R. and D. Siegel (1986). The value of waiting to invest. The Quarterly Journal of Economics 101(4), 707-727.

Megginson, W. (2005). The Financial Economics of Privatization. Oxford University Press.

Nordal, K. B. (2001). Country risk, country risk indices and valuation of fdi: a real options approach. Emerging Markets Review 2(3), 197-217.

Pennings, E. (2000). Taxes and stimuli of investment under uncertainty. European Economic Review 44(2), 383-391.

Postali, F. A. S. (2009, December). Petroleum royalties and regional development in Brazil: The economic growth of recipient towns. Resources Policy 34(4), 205-213.

Raff, H. (1992). A model of expropriation with asymmetric information. Journal of International Economics 33(3), 242-265.

Renn, O., A. Jovanovic, and R. Schröter (2011). Social unrest. Technical report, IFP/WKP/FGS (2011) 5, OECD/IFP Project on Future Global Shocks, Paris: OECD. 
Rigobon, R. (2010). Dealing with Expropriations: General Guidelines for Oil Production Contracts. In W. Hogan and F. Sturzenegger (Eds.), The Natural Resources Trap: Private Investment Without Public Commitment, pp. 227-254. MIT Press.

Schnitzer, M. (2002). Debt v. foreign direct investment: the impact of sovereign risk on the structure of international capital flows. Economica 69(273), 41-67.

Schwartz, E. and A. Trolle (2010). Pricing expropriation risk in natural resource contracts: A real options approach. In W. Hogan and F. Sturzenegger (Eds.), The Natural Resources Trap: Private Investment Without Public Commitment, pp. 263-288. MIT Press.

Shleifer, A. (1998). State versus private ownership. The Journal of Economic Perspectives 12(4), $133-150$.

Stiglitz, J. (2000). Economics of the Public Sector (Third ed.). W.W. Norton \& Company.

Stroebel, J. and A. van Benthem (2010). Resource extraction contracts under threat of expropriation: Theory and evidence. USAEE/IAEE Working Paper, 1-38.

Thomas, J. and T. Worrall (1994). Foreign direct investment and the risk of expropriation. The Review of Economic Studies 61(1), 81-104.

Tomz, M. and M. L. J. Wright (2010). Sovereign Theft: Theory and Evidence about Sovereign Default and Expropriation. In W. Hogan and F. Sturzenegger (Eds.), The Natural Resources Trap: Private Investment Without Public Commitment, pp. 69-110. MIT Press.

\section{Appendices}

\section{Proof of Proposition 1}

Essential The government has no option to abandon this project. Therefore, the constant $B_{4}$ from equation 5 is equal to zero. Besides, recall that $B_{3}=0$ (from equation 9). Replacing these two conditions in equation 5 yields the value of the claim for public provision in utilities.

Non Essential The first value matching condition is given by the fact that if the cash flows are very large, then the government will never abandon the project, so that the present value of the project in those cases is simply the value of the operating facility (eq. 50). The second value matching condition (eq. 49), is related with the option to abandon. Having this option makes the constant $B_{4}$ positive, and it means that there is a level of cash flows, $x_{a}$, in which the government stops operations and abandons the project with a net salvage value of zero. The abandonment trigger, $x_{a}$ is determined by the smooth pasting condition (eq. 51).

$$
\begin{gathered}
G^{c}\left(x_{a}\right)=0 \\
\lim _{x \rightarrow \infty} G^{c}(x)=\frac{x}{\delta}-\frac{c_{g}}{r} \\
\left.\frac{\partial G^{c}(x)}{\partial x}\right|_{x=x_{a}}=0
\end{gathered}
$$


Proof of Proposition 2 In this case, the option value is equivalent for the two sectors, $i=u, c$. In order to obtain a particular solution for equation 2, we impose three conditions. The first one is that $B_{2}=0$ (from eq. 4 ): it ensures that the option value goes to zero for small values of $x$, where the option is very out of the money. The second one is a value matching condition: it simply states that at the moment of investment, the option to invest will be worth as much as the operating project, deducting the investment cost (eq. 52). Finally, the smooth pasting condition, says that the level of cash flows at which investment will be carried out is optimally chosen (eq. 53).

$$
\begin{gathered}
G_{0}^{i}\left(x_{I}\right)=G^{i}\left(x_{I}\right)-I_{g} \\
\left.\frac{\partial G_{0}^{i}(x)}{\partial x}\right|_{x=x_{I}}=\left.\frac{\partial G^{i}(x)}{\partial x}\right|_{x=x_{I}}
\end{gathered}
$$

Proof of Proposition 3 The private firm has two value matching conditions. The first one makes $B_{3}=0$, since as long as cash flows are high enough (eq. 55) the private firm will continue operations. The second one describes the option to abandon: the constant $B_{4}$ is positive and adds value to the claim of the private firm. Upon abandonment, at the cash flows level $x_{a}^{s}$, the project is worth zero (eq. 54). The abandonment trigger is set through the smooth pasting condition (eq. 56).

$$
\begin{gathered}
V^{s}\left(x_{a}^{s}\right)=0 \\
\lim _{x \rightarrow \infty} V^{s}(x)=\frac{x}{\delta}(1-\rho)(1-\tau)-\frac{c_{v}}{r}(1-\tau) \\
\left.\frac{\partial V^{s}(x)}{\partial x}\right|_{x=x_{a}^{s}}=0
\end{gathered}
$$

The government's claim is related to whether it has the abandonment option or not if firm abandons the project. Therefore, we have one value matching condition for each sector.

Essential The government has to take the project, disregarding possible losses. The value matching condition 57 states that, upon the firm's abandonment, the claim for the government is the same as in the case of public provision.

$$
G^{u s}\left(x_{a}^{s}\right)=G^{u}\left(x_{a}^{s}\right)
$$

Non Essential The government takes the project after the firm's abandonment, if and only if $\frac{c_{v}}{c_{g}}>(1-\rho)$, since this implies that the private will abandon earlier than the government $\left(x_{a}^{s}>x_{a}\right)$. Thus, the value matching condition will be equation 58. Otherwise, the government does not take the project after the firm abandons. Thus its value when the firm abandons is equal to zero (eq. 59).

$$
\begin{gathered}
G^{c s}\left(x_{a}^{s}\right)=G^{c}\left(x_{a}^{s}\right) \\
G^{c s}\left(x_{a}^{s}\right)=0
\end{gathered}
$$


Proof of Proposition 4 The private firm has one value matching condition (eq. 60) from which the value of the option at the moment of investment is equal to the value of the project when cash flows are equal to $x_{I}^{s}$ minus the investment cost. The smooth pasting condition 61 allows to find the investment trigger of the private firm.

$$
\begin{gathered}
V_{0}^{s}\left(x_{I}^{s}\right)=V^{s}\left(x_{I}^{s}\right)-I_{v} \\
\left.\frac{\partial V_{0}^{s}(x)}{\partial x}\right|_{x=x_{I}^{s}}=\left.\frac{\partial V^{s}(x)}{\partial x}\right|_{x=x_{I}^{s}}
\end{gathered}
$$

The government has one value matching condition (eq.62) that shows that its claim on the private firm's investment option is equal to its claim on the operating project when cash flows are equal to the investment trigger $x_{I}^{s}$.

$$
G_{0}^{i s}\left(x_{I}^{s}\right)=G^{i s}\left(x_{I}^{s}\right)
$$

Proof of Proposition 5 Besides the option to abandon the project (eq. 63), which happens at the cash flows level $x_{a}^{e}$, the firm has to account for the possibility of being expropriated and receive a fixed compensation, $k_{v}$ (eq. 64). The smooth pasting condition (eq. 65) indicates that the abandonment trigger is optimally chosen by the firm, accounting for the possibility of expropriation.

$$
\begin{gathered}
V^{e}\left(x_{a}^{e}\right)=0 \\
V^{e}\left(x_{e}\right)=k_{v} \\
\left.\frac{\partial V^{e}(x)}{\partial x}\right|_{x=x_{a}^{e}}=0
\end{gathered}
$$

The government also has two value matching conditions and one smooth pasting condition. The first condition (eq. 66) is related with the case of abandonment of the private firm, and works the same as in the safe case: depending on the sector, $i=u, c$, the government has the option to skip the project's operation (commodities if $x_{a}>x_{a}^{e}$ ) or not (utilities). The second one determines that the value of the government's claim upon expropriation is the value in the public provision case of Proposition 1, minus the costs of expropriation (eq. 67). Finally, the smooth pasting condition states that the expropriation trigger, $x_{e}$, is optimally chosen by the government (eq. 68).

$$
\begin{gathered}
G^{i e}\left(x_{a}^{e}\right)=G^{i}\left(x_{a}^{e}\right) \\
G^{i e}\left(x_{e}\right)=G^{i}\left(x_{e}\right)-k_{v}-k_{r} \\
\left.\frac{\partial G^{i e}(x)}{\partial x}\right|_{x=x_{e}}=\left.\frac{\partial G^{i}(x)}{\partial x}\right|_{x=x_{e}}
\end{gathered}
$$

Proof of Proposition 6 There are two conditions imposed on equation 2 in order to obtain a particular solution for the option value to the private firm. The value matching condition states that when the cash flows reach the investment trigger of the firm, $x_{I}^{e}$, the value of the option to invest equals the value of the project, accounting for the threat of expropriation, minus the investment cost (eq. 69). The smooth pasting condition (eq.70) indicates that $x_{I}^{e}$ is optimally chosen. 


$$
\begin{gathered}
V_{0}^{e}\left(x_{I}^{e}\right)=V^{e}\left(x_{I}^{e}\right)-I_{v} \\
\left.\frac{\partial V_{0}^{e}(x)}{\partial x}\right|_{x=x_{I}^{e}}=\left.\frac{\partial V^{e}(x)}{\partial x}\right|_{x=x_{I}^{e}}
\end{gathered}
$$

As for the government, in either sector, it only has one value matching condition (eq.71) that shows that its claim on the private firm's investment option is equal to its claim on the operating project at the investment trigger $x_{I}^{e}$ level of cash flows.

$$
G_{0}^{e}\left(x_{I}^{e}\right)=G^{e}\left(x_{I}^{e}\right)
$$

